\title{
Measuring links between labor monopsony and the gender pay gap in Brazil
}

\author{
Brandon Vick (1)
}

Correspondence:

brandon.vick@iup.edu

Department of Economics, Indiana

University of Pennsylvania, 441

North Walk, Indiana PA 15705, USA

\begin{abstract}
This paper focuses on gender differences in job mobility and earnings for workers in Brazil. Monopsony theory suggests a link between the wage elasticity of labor supply and wage penalties. Should one group of workers be less elastic in their supply choices, that group is predicted to earn less than others. To measure wage elasticity, I estimate a hazard model on voluntary job separations using the RAIS, a linked employer-employee dataset that captures formal-sector workers' job durations over time. Four models are specified and point to significant gender differences. Across the models, male elasticity ranges from 1.638 to 2.175 while female elasticity ranges from 1.22 to 1.502 . The female wage penalty predicted by these elasticity differences ranges from 11.4 to $20.5 \%$, compared to an actual gender wage difference of $16.4 \%$. Results of higher male elasticity are robust to the use of a more parsimonious specification, a discrete-time approach, the use of job spell data for a single year, and disaggregation by region. I extend the model through decomposition methods to help clarify the association between earnings, job separations, and elasticity.
\end{abstract}

JEL Classification: J31, J42, J64, C12, J64

Keywords: Gender wage gap, Labor supply, Monopsony, Separation elasticity, Brazil

\section{Introduction}

Do gender differences in job mobility explain gender differences in pay? This paper is concerned with the ability of workers to make transitions from their jobs in response to wage signals. One possible barrier to job transitions may be a lack of other job opportunities due to few employers in the labor market-the situation of monopsony. Other reasons relate to an inability to move from one's job even when other employment opportunities are available. A worker may have poor information about these opportunities or may not have the time to search them out. Or a worker may know about other jobs but cannot afford to make such a transition, either due to high switching costs or the high risk put on a worker and her family.

This paper uses a dynamic monopsony model that formalizes these constraints to job movement into one theoretical framework and describes how the wage elasticity of labor supply captures a worker's ability to change jobs in response to wage offers (Manning 2003). The monopsony model predicts that labor supply elasticity is positivethat workers are more likely to leave a low-paying than a high-paying job and that firms attract more workers with higher wage offers. The model also predicts a relationship between wage elasticity and earnings differences, illustrated as follows: in a labor market

(c) The Author(s), 2017 Open Access This article is distributed under the terms of the Creative Commons Attribution 4.0 International License (http://creativecommons.org/licenses/by/4.0/), which permits unrestricted use, distribution, and reproduction in any medium, provided you give appropriate credit to the original author(s) and the source, provide a link to the Creative Commons license, and indicate if changes were made. 
where job-search frictions are prevalent, differences in workers' job mobility (measured through wage elasticity) can result in earnings differences between them, despite similar education or occupational choices. Should female workers have lower elasticity than male workers, either due to preferences (i.e., the trade-off for stability over wage) or constraints (i.e., poorer information), females would have less ability to move to higher-paying jobs compared to males, resulting in an earnings gap.

Better understanding the potential relationship of labor monopsony and gender mobility differences requires information on the firms hiring and paying workers. Such firms may possibly impose pay structures to the disadvantage of groups with lower wage elasticity of labor supply. For this paper, I use an employer-employee-linked dataset for Brazil to estimate the dynamic monopsony model. Setting the analysis in a middle-income economy (MIC) is a major contribution to the study of monopsony, as higher poverty rates, less developed transportation infrastructure, fewer education opportunities, and lower unionization rates may play a role in creating market frictions that hinder job mobility.

With the Brazilian Relação Anual de Informações Sociais (RAIS) data, I control for both worker and firm variables to estimate elasticity. To test the relationship between job transitions and actual earnings differences, I estimate labor supply elasticities for males and females separately. Two tests of the results follow: first, estimated standard errors allow for significance testing on gender differences in elasticity. Second, actual gaps in mean wages are compared to gaps predicted by male-female differences in elasticity.

In addition, I propose a number of improvements and checks to the methods that have been employed in previous monopsony studies. First, I am able to differentiate voluntary from involuntary separations (i.e., quits from layoffs). Worker movements toward better offers drive the dynamics of the monopsony model. The inclusion of layoffs in the data may confuse estimates based on worker movements. Second, I estimate separation elasticities over various specifications of hazard models to check robustness and test for various assumptions of these techniques. Third, I perform statistical tests of gender differences and discuss the effects such testing may have for related studies.

Elasticity has a very straightforward, inverse relationship to earnings in monopsony theories. In actual markets, this relationship may be complicated over the diversity of workers and regions in Brazil. To help clarify the association between earnings and elasticity, I extend the model through disaggregation and decomposition. The first extension compares gender differences in elasticity to earnings by region and sector subgroups for Brazil. The second extension more closely analyzes empirical aspects of the job separation regression, which is the fundamental model used in estimating wage elasticity. I use non-linear decomposition methods to analyze the role that wage plays relative to other factors in worker separations and how this differs across gender.

\section{Background: linking dynamic monopsony to the gender wage gap}

The ideas of labor monopsony were first formulated by Pigou (1924) and Robinson (1933). A monopsony employer lacks competition from other firms in the demand for labor. The measure of monopsony power is related to the wage elasticity of labor supply-the extent that workers respond to a lower wage by leaving the market. In a labor market with perfect competition, a firm faces a labor supply with infinite wage elasticity, meaning that if the firm decreases wages below the market wage, workers will quit and look for work at a higher-paying competitor. A monopsonistic firm, on the other hand, faces a labor supply 
elasticity that is much lower; if the firm lowers wages, not all workers will leave the firm. The lower the wage elasticity of supply, the more likely workers are to stay with the firm at a lower wage.

\subsection{Market imperfections constraining labor mobility}

Barriers to entry may exist for competing firms, or a lack of competing firms may limit outside job opportunities (Lester 1952). Even in the case of many firms, employers may be able to exert wage-setting monopsony power if workers are unable to seek out betterpaying jobs or there is a lack of such jobs. Such a state of the labor market may exist due to various market imperfections. Three categories of such imperfections are described here.

Imperfect information and search costs: Workers may have limited knowledge of outside job opportunities (Stigler 1962; Stiglitz 1989). The ability to thoroughly search for viable job opportunities is critical to someone finding work that pays a wage commensurate with her skills and productivity. The costlier this search, in time or resources, the less one can afford to spend searching, lowering the probability of finding a higher-paying job. Employers are potentially able to discriminate by differences in search costs, paying workers with high search costs lower wages on average than workers with lower search costs.

Switching costs: Workers may have mobility problems, an inability or unwillingness to migrate to higher-paying jobs, possibly due to high moving costs or poor infrastructure. Even if the access to information is good and search costs are manageable, many difficulties to job switching remain. Psychological barriers in the form of loyalty to an employer may dissuade search for some time. The skills and training a worker receives may be specific to the current firm and not transferrable or desirable to other employers. When considering moving geographically to take a new job, moving costs and leaving one's friends and family may also dissuade switches.

Vulnerability to shocks: Workers living in or near poverty may not be able to afford being unemployed for a period of time and thus forgo the risk of finding new jobs (Smith 1776). The credit market plays a crucial role in the theory of labor supply (Skoufias 1996; Blundell and Macurdy 1999). Generally, constraints to borrowing, insurance, and savings services make one more vulnerable to various health and income shocks. This can lead workers to be more risk averse, prioritizing a stable income source. In the face of risk, workers have been found to take lower pay and work greater hours to prepare for the potential of large, negative shocks (Behrman 1999). A worker in these circumstances may be less likely to leave current employment if looking for better work jeopardizes that job or takes time away from it.

The severity of these imperfections will vary across individuals, communities, industries, and countries. In some contexts, a worker may only face mobility problems for a limited time, until new information becomes available. In other settings, perhaps for workers in lower- or middle-income countries (LMICs), the inability to find another job may persist for much longer, possibly due to a lack of other opportunities or means to move to another location.

\subsection{Dynamic monopsony and pay gaps}

Recent theoretical and empirical work is informing economic thinking regarding the circumstances in which monopsonistic behavior may take place. Equilibrium labor search 
and matching models (Diamond 1982; Mortensen and Pissarides 1994) formalize many barriers to perfectly competitive markets that may impede a worker's transition to another job, including limited information, wage bargaining, and matching problems between firms and workers. Based on the model of Burdett and Mortensen (1998), Manning (2003) formulates a dynamic monopsony model, focusing on the idea of "labor supply to the firm," where market-wide rates of job recruitment, job separation, and unemployment create an interrelation between supply and demand. Since any worker can experience difficulties finding or moving to a new job, a given firm may have some level of monopsony power regardless of the number of other employers in the market. Some firms can offer relatively low wages because some workers will not receive better job offers, leading to wage dispersion. Thus, monopsony power may be based on more than a lack of other job opportunities in the market. The worker's lack of knowledge of these opportunities may also create a situation in which employers can lower wages in a monopsonistic way.

Manning (2003) lays out an empirical framework for estimating the wage elasticity of labor supply, described in the next section. He combines methods for analyzing worker transitions to and from jobs over time with the concept of the monopsony rate of exploitation, introduced by Pigou (1924) and Robinson (1933) and defined by Eq. (1). First, market frictions can result in an upward-sloping labor supply curve facing the firm. The firm's ability to pay below the employee's marginal revenue product is inversely proportional to the wage elasticity of labor supply $\epsilon_{l, w}$ facing a particular firm:

$$
\frac{\mathrm{MRP}_{l}-w}{w}=\frac{1}{\epsilon_{l, w}} .
$$

In perfect competition, $\epsilon_{l, w}=\infty$ and monopsony power is zero. In markets further removed from perfect competition (i.e., those with few employers, little information about other jobs, or large inability of workers to change jobs), $\epsilon_{l, w} \rightarrow 0$ and monopsony power over wages increase.

Second, in an imperfect labor market, differences in $\epsilon_{l, w}$ among similar workers (i.e., those who are realistically competing for the same job and have similar education, experience, and skill) can result in pay gaps between them, summarized by comparing the mean worker from two groups $a$ and $b$, as follows:

$$
\frac{\epsilon_{l, w}^{a}-\epsilon_{l, w}^{b}}{\epsilon_{l, w}^{b}\left(\epsilon_{l, w}^{a}+1\right)}=\ln (\text { wage })^{a}-\ln (\text { wage })^{b} .
$$

In other words, the group with lower relative elasticity of supply will work for relatively less pay in a monopsonistic labor market.

A discussion about job mobility is especially relevant to the subject of gender earnings differences, as female workers are paid less than males in many countries around the world (Nopo et al. 2011). Females may face greater barriers in terms of the market frictions that serve to limit a worker's ability to move to a better job. A number of genderspecific factors may lower the outside job opportunities accessible to females, such as lower education limiting the access to higher-paying jobs, discrimination against females limiting the offers they receive, or cultural norms limiting females to certain types of jobs or sectors. Due to greater family and household responsibilities, women may have less time to conduct job searches or they may have greater risk aversion toward switching jobs. Less access to banking and insurance services for women, as in the context of many 
poor countries, may also induce them to stay in the current job rather than risk starting a new job. Additionally, due to gendered cultural constraints, female workers may sort into occupations that offer greater workplace flexibility, whereas men, having less cultural constraints or family responsibilities, would be compensated more for sacrificing such flexibility (Goldin 2014).

Recent research has employed the monopsony model to measure gender pay gaps. Hirsch et al. (2010) used Manning's empirical framework and linked employer-employee data in Germany to estimate labor supply elasticity controlling for individual- and firmlevel fixed effects. The authors found lower elasticity for women compared to men and suggested that wage discrimination by monopsonistic employers accounted for at least one third of the observed gender pay gap. Similarly, Barth and Dale-Olsen (2009) modeled firm-level wage policies and found that gender elasticity differences accounted for 70 to $90 \%$ of the gender wage gap for low-education workers. Hirsch and Jahn (2015) found that estimated elasticity differences predicted the native-immigrant wage differential in Germany. In perhaps the broadest implementation of the model to date, Webber (2015) used Longitudinal Employer-Household Dynamics (LEHD) data to estimate individual labor supply elasticities facing every US firm. The author found that a one-unit increase in elasticity was associated with wage gains of 5 to $16 \%$, on average. The author also found significant variability across firms, with firms at the lower end of the wage distribution exerting the most wage-setting power.

While some studies have estimated labor elasticities for entire labor markets, such as Germany (Hirsch and Jahn 2015), Australia (Booth and Katic 2011), or the USA (Manning 2003; Webber 2015), a number have focused their studies on specific markets. Depew and Sorensen (2011) estimated changes in worker elasticity due to business cycles for two firms: Ford Motors and A.M. Byers. The authors found that both firms exerted significant wage-setting power and that labor-supply elasticity was lower during recessions. Studying a chain of grocery stores, Ransom and Oaxaca (2010) used exogenous wage changes to estimate labor supply elasticity and found lower female elasticity. Fox (2010) found that younger engineers supply labor more elastically than older engineers in Swedish firms, a result of lower switching costs. Falch (2010) used a quasi-natural experiment in Norway to identify changes in the excess demand for teachers due to wage premiums for less supplied regions. The wage changes were determined by countrywide central planning and treated as exogenous. The authors used school fixed-effects models and found that the average elasticity of supply ranges from 1.0 to 1.9 , suggesting substantial short-run monopsony power. Ransom and Sims (2010) used pre-negotiated salary schedules as an instrument for actual teacher salaries in Missouri and found evidence of market power by school districts. The authors suggested restricted teacher mobility due to pension schemes in Missouri as a potential mechanism for greater monopsony power. While Ransom and Oaxaca (2010), Booth and Katic (2011), and Hirsch et al. (2010) compared supply across gender and Fox (2010) across age, few studies of dynamic monopsony have tested for heterogeneity across other relevant variables, such as sector or region, as done here.

\subsection{The Brazilian earnings gap}

The recent work on monopsony has not addressed some issues important to labor market policy and human development. Few studies have attempted to measure monopsony power in LMICs, where it can be argued that many of the labor market imperfections 
mentioned above are more prevalent. One related study, Brummund (2013), provides evidence of monopsony in Indonesian manufacturing firms by comparing wages to estimated marginal revenue products of labor. More generally for LMICs, higher poverty rates, greater difficulty in starting businesses, poorer information technology and transportation infrastructure, fewer education opportunities, and lower unionization rates may play a role in creating greater market imperfections.

Additionally, inelastic labor supply may have different implications for trade, labor, and human development policies in LMICs. For example, monopsony models suggest that minimum wages could lead to an increase in employment, compared to neoclassical predictions of disemployment. However, many LMICs may lack the institutional ability to enforce a minimum wage (Danziger 2009). Additionally, larger informal sectors and more widespread discrimination in many LMICs are especially harmful to female equality and mobility (Chioda 2011; World Bank 2012). Applying methods to understand the effects of mobility on earnings can inform policy responses to gender inequality. Regarding trade policy, export firms may require a large scale to compete globally, but such scale could have monopsony effects that increase wage inequality (Helpman et al. 2010).

Brazil provides a good case study for better understanding the complex interactions between the gender earnings gap, firm characteristics, and job mobility. The earnings gap in Brazil has narrowed over the past 30 years. This is due in part to increased access to education for females (Arabsheibani et al. 2003; Garcia et al. 2009) and female entry into traditionally male occupations (Madalozzo 2009). The gap persists, however, with some evidence of continued discrimination against female workers (Loureiro et al. 2004; Arbache and Loureiro 2012). The large overrepresentation of females in the informal sector is additionally problematic, as informal workers experience longer spells of poverty, higher structural deprivation, and a higher degree of exposure to shocks (Machado et al. 2007). Related to mobility is the finding that informal female workers face more transitory poverty (Ibid.).

\section{Methods}

\subsection{Estimating labor supply elasticity}

The Burdett and Mortensen (1998) model of labor predicts that steady-state wage dispersion occurs despite the presence of many employers in the market. Wage offers are continuously distributed across all firms; firms offering high wages hire more workers but make lower profits per worker. Search-and-matching frictions create differences in the wage offers that workers receive. Some receive wage offers at the reservation rate, inducing them out of non-employment, while others receive offers higher than current wages, inducing them to move out of a lower-paying job. The labor supply of a firm is determined by the number of recruits it attracts (rising with wage) and the rate of separation (decreasing with wage). The behavior and flow of these separation and recruitment decisions is the most important idea of monopsony theory and informs the empirical analysis-the elasticity of labor supply is determined by the wage elasticity of separation and recruitment.

Manning (2003) outlines an empirical implementation of this model. For the cumulative distribution function of job offers across all firms $F(w) \in[0,1]$, a wage offer $w=w_{1}$ is higher than $F\left(w_{1}\right)$ of all other offers. $L(w, F)$ is the firm size-wage and $R(w, F)$ the recruitment-wage relation functions that prevail when the market is in steady state. A 
firm in steady state balances separations and recruits to maintain its labor supply:

$$
s(w) L(w, F)=R(w, F) .
$$

Differentiating the natural logarithm of each side of this steady-state definition yields an equation for the wage elasticity of labor supply to the firm in terms of the wage elasticity of recruitment and separations:

$$
\epsilon_{l, w}=\epsilon_{r, w}-\epsilon_{s, w}
$$

Currently employed workers see their jobs destroyed at rate $\delta$ and unemployed workers find jobs according to the job arrival process $\lambda$, giving the evolution of unemployment:

$$
\dot{u}=\delta(1-u)-\lambda u \text {. }
$$

Workers separate from current employment because of either job destruction or an opportunity to move to a higher-paying job. Employers recruit from the pool of unemployed by offering at least the reservation wage $(b)$ or from employed workers by offering a wage higher than what the worker is currently making. Suppose $s(w)$ and $R(w, F)$ take the following forms:

$$
\begin{aligned}
s(w) & =\delta+\lambda(1-F(w)) \\
R(w, F) & =\lambda u+\lambda \int_{b}^{w} f(x) L(x) d x .
\end{aligned}
$$

Calculating the elasticities of separations and recruitments with respect to wage leads to a simplification of the wage elasticity Eq. (4):

$$
\begin{aligned}
\frac{w s^{\prime}(w)}{s(w)} & =\frac{w R^{\prime}(w)}{R(w)} \\
\epsilon_{s, w} & =-\epsilon_{r, w} \\
\epsilon_{l, w} & =-2 \epsilon_{s, w} .
\end{aligned}
$$

Thus, the overall wage elasticity can be estimated based only on the separation elasticity, which can be found more easily in survey data. A slight extension allows for differences in separations going to employment vs. non-employment $(e, n e)$, weighted by the proportion of the former $\left(\theta_{s}\right)$ :

$$
\epsilon_{l, w}=-2\left(\theta_{s} \epsilon_{s, w}^{e}+\left(1-\theta_{s}\right) \epsilon_{s, w}^{n e}\right) .
$$

In order to compare elasticity between two groups and calculate the expected pay difference between the two, the researcher must specify a model to estimate the effect that wage has on the probability of separating from a job spell to other employment (effect $\epsilon^{e}$ ) and the probability of separating to non-employment (effect $\epsilon^{\text {ne}}$ ).

\subsection{Hazard modeling of voluntary job separations}

To begin my analysis, I utilize methods outlined by Hirsch et al. (2010) and Manning (2003), described here. I estimate an exponential proportional hazard model with timevarying covariates to model the instantaneous separation rate to employment and nonemployment $s_{i}^{v}$ with $v=e, n e$. Separation from job spell $i$ may occur anytime over the course of the worker's tenure $t$. This is conditional on the following factors:

- Wage at the job $w_{i}(t)$, the primary variable of interest;

- A vector of other observable time-varying characteristics of the worker $x_{i}(t)$; 
- A vector of time-varying characteristics of the firm at the time of job spell $z_{j(i)}(t)$; and

- A term for either unobserved individual or firm heterogeneity $v_{i, j(i)}$.

The model for the conditional hazard function is

$$
s_{i}^{\nu}\left(t \mid w_{i}(t), x_{i}(t), z_{j(i)}(t), v_{i, j(i)}\right)=v_{i, j(i)} s_{0}^{\nu}(t) \exp \left[w_{i}(t) \beta^{\nu}+x_{i}(t) \alpha^{\nu}+z_{j(i)}(t) \gamma^{\nu}\right]
$$

This functional form assumes a constant baseline hazard $s_{0}^{v}(t)$ over time. I employ a piecewise-constant baseline hazard with worker-job spell observations for each year of analysis (1998-2001) and include year dummy variables. This allows for year-to-year differences in the baseline hazard curve (Cleves et al. 2008).

Unobserved quantities $v_{i, j(i)}$ may enter into the hazard function $s_{i}^{\nu}$, either within workers experiencing multiple job spells over time or within firms over multiple coworkers. If such job quit similarities are correlated between spells for the same worker or between coworkers of the same firm, effects from endogeneity may bias estimates. Shared frailty models account for intra-group correlation, assuming the shared frailty is gamma distributed with mean 1 and variance $\theta$ (Cleves et al. 2008). Along with reporting estimates for the specification of $s_{i}^{v}$ not accounting for such correlations, I estimate and report a worker-shared frailty model and a firm-shared frailty model. I also report results of the likelihood-ratio test of $H_{0}: \theta=0$, the null hypothesis of no within-group correlation.

\subsection{The Brazilian RAIS}

Firm- and worker-level heterogeneity can be accounted for by using employer-employeelinked, panel datasets. The RAIS records details of uniquely identified workers' education, age group, tenure, and pay for job spells with uniquely identified firms for all formally employed workers in Brazil. Additionally, the data contain $\mathrm{CBO}$ occupation codes, month and year of hire, month of separation, reason for separation, and municipality. Firm characteristics include Instituto Brasileiro de Geografia e Estatística (IBGE) sector codes, number of workers, the proportions of primary and high school educated workers, and the percentage of white-collar workers.

Brazilian law requires all private- and public-sector firms to report this information to the ministry of labor Ministério de Trabalho (MTE), covering every employee that worked at the firm in the past year. Employees have incentives to make sure accurate data is collected in the RAIS, as public wage supplements are based on this data. Additionally, fines may be issued to firms failing to comply. The MTE estimates that the RAIS covers over $90 \%$ of formal employees in the 1990 s and $97 \%$ in $2011 .^{1}$

While the detailed information captures necessary observable characteristics for estimating elasticity for formal workers, the RAIS lacks information for informal workers and those out of the labor force. Selection effects into formal work, and how these may bias estimates of elasticity, cannot be accounted for within the RAIS data. However, in their study of wage determinants using the RAIS, Filho et al. (2006) calculate selection probabilities from the PNAD household survey and find that selectivity into formal employment does not affect their estimates. Potential selection effects on elasticity estimation are beyond the scope of this paper.

Menezes-Filho and Muendler (2011) constructed a 10\% random sample of workers, following their job paths from 1986 to 2001. To avoid potential confounding effects of trade 
liberalization and privatization reforms implemented in the early 1990s (Menezes-Filho and Muendler 2011), I use this sample for the 4 years 1998 through 2001 to estimate separation probability for job spell $i$ at time $t$ tenure with the firm. Similar to Menezes-Filho and Muendler (2011) and Webber (2015), I keep only the highest-paying job for individuals holding multiple jobs. I restrict the analysis to separations from the last employment spell in the calendar year, as in Menezes-Filho and Muendler (2011) for their study of job reallocation.

With details on the reason for separation, I can distinguish between workers who quit from those who are laid off. I do not count separations due to death, retirement, or transfer. The ability to isolate quits greatly enhances the economic interpretation of results, as the transitions in the monopsony model and the idea of labor supply are based on a worker's wage considerations. Few studies have been able to isolate job quits in monopsony model estimations (Booth and Katic 2011; Depew and Sorensen 2011). Although Depew and Sorensen (2011) differentiate quits from layoffs in their study of Ford, the lack of such information is a major gap in empirical studies of broader labor markets. For example, Webber (2015) and Hirsch et al. (2010) cannot distinguish between quits and layoffs. Ransom and Oaxaca (2010) make the assumption that all measured separations are due to quits but cannot differentiate quits from layoffs. Additionally, Webber (2015), using US LEHD data, states that it is difficult to distinguish separations to employment from those to non-employment.

For the primary analysis, I define a separation to employment as a worker quit from a job spell that results in a new job spell within the next month. I define a separation to non-employment as a worker quit that does not result in a new job spell within the next month. To measure how layoffs may affect elasticity calculations, I also estimate separation elasticities based on involuntary separations.

Worker and firm controls are included in each model estimation and presented in Table 8 in the Appendix. I measure the monthly wage rate as the log of deflated monthly earnings. ${ }^{2}$ I include workers between 20 and 49 years to avoid retirement considerations of workers in their late careers. Worker controls include age, education, occupation, sector, and region categories. Potential experience, measuring the number of years since completing education, and its square are also included in regression estimations. Firm controls include the $\log$ of the number of employees, the firm workforce proportions of primary- and high school education, and the percentage of white-collar workers. ${ }^{3}$

\subsection{Statistical testing}

To test the plausibility of wage elasticity differences as an explanation of earnings gaps, I estimate separation models for males and females separately, allowing for two tests of the results. First, both the gender difference in elasticity and the implied gap are directly tested for statistical significance. Second, actual differences in mean ln(wage) across gender are compared to differences in $\epsilon_{l, w}$ estimates, as in Eq. (2). Statistical testing of elasticity is not a straightforward endeavor, as elasticity and standard errors are calculated from the non-linear combination of coefficients from multiple regressions. The interpretation of results depends on whether gender elasticity differences are significant or not, with non-significance suggesting that there is no gender difference in elasticity and thus no effect of elasticity differences on the earnings gap. Such testing has largely been left unchecked in previous studies using this model. Depew and Sorensen (2011) 
present bootstrapped standard errors with their estimates but do not perform gender comparisons. Hirsch and Jahn (2015) calculate elasticity standard errors and test for equality between native vs. immigrant workers in Germany; however, they do not calculate standard errors for the implied wage gap. For non-frailty models, combined elasticity variance-covariance matrices are computed by Taylor linearization, using Stata's "suest" package. The standard errors for elasticity $\epsilon_{l, w}$ are based on the delta method and calculated using the non-linear combination program "nlcom." Additionally, both male and female estimates are combined using "suest," and direct tests of significance are performed. ${ }^{4}$

\section{Results}

I calculate the earnings gap expected if monopsonistic firms pay different wages based on gender elasticity differences. In addition to the primary specification, I estimate models including shared individual and firm frailties, models comparing voluntary vs. involuntary separations, and models with alternative hazard specifications.

\subsection{Elasticity results and the gender wage gap: full model}

This section presents male and female elasticity estimates calculated from Eq. (9) restated in terms of estimated $\beta$ values:

$$
\epsilon_{l, w}=-2\left(\theta_{s} \beta^{e}+\left(1-\theta_{s}\right) \beta^{n e}\right),
$$

where $\beta^{e}$ is the $\ln$ (wage) coefficient from the hazard model in Eq. (10) for job separations to employment, $\beta^{\text {ne }}$ is the $\ln$ (wage) coefficient from the hazard model in Eq. (10) for job separations to non-employment, and $\theta$ is the proportion of separations that result in other employment.

The dynamic monopsony model assumes workers behave in certain ways; the economic interpretation of estimates for separation wage coefficients and the labor supply elasticity requires that estimates have a certain sign. Coefficients $\beta^{e, n e}$ are expected to be negative, indicating that a wage increase is associated with a decreased probability of quitting a job (or that a wage decrease is associated with an increased quit probability). If $\beta^{e, n e}$ estimates are negative, then $\epsilon_{l, w}$ is positive, as calculated in Eq. (11), indicating that labor supply increases with wage. Additionally, if elasticity differences are related to earnings differences, as in Eq. (2), the group with the higher wage should have a higher separation response to a pay decrease. Or, if $\left(\left|\beta_{m}^{e, n e}\right|>\left|\beta_{f}^{e, n e}\right|\right)$, then mean male wages are predicted to be greater than female wages. For the RAIS sample, male wages are $16.4 \%$ higher on average than female wages.

A first look at results examines whether $\beta^{e, n e}$ coefficients are statistically significant and less than zero. Table 1 shows this to be the case across various models: (1) no firm controls, (2) with firm controls, (3) with controls and individual frailties/fixed effects, and (4) with controls and firm frailties. For both separations to employment and non-employment (rows (a) and (b) respectively), the male wage coefficient is larger in magnitude than the female one, suggesting stronger separation responses for male workers. Estimates for $\theta$ show the proportion of quits to employment/all quits and are close to $2 \%$ for both males and females, which results in overall elasticity being weighted heavily on separations to non-employment. 
Table 1 Estimates of wage elasticity of labor supply and implied pay gaps

\begin{tabular}{|c|c|c|c|c|c|c|c|c|}
\hline \multirow[b]{4}{*}{ Parameter } & \multicolumn{8}{|l|}{ Model } \\
\hline & \multirow{2}{*}{\multicolumn{2}{|c|}{$\begin{array}{l}\text { (1) } \\
\text { No firm controls }\end{array}$}} & \multirow{2}{*}{\multicolumn{2}{|c|}{$\begin{array}{l}\text { (2) } \\
\text { With firm controls }\end{array}$}} & \multirow{2}{*}{\multicolumn{2}{|c|}{$\begin{array}{l}\text { (3) } \\
\text { Individual frailties }\end{array}$}} & \multirow{2}{*}{\multicolumn{2}{|c|}{$\begin{array}{l}\text { (4) } \\
\text { Firm frailties }\end{array}$}} \\
\hline & & & & & & & & \\
\hline & Male & Female & Male & Female & Male & Female & Male & Female \\
\hline (a) $\beta^{e}$ & $\begin{array}{l}-0.652 \\
(.035)^{* *}\end{array}$ & $\begin{array}{l}-0.306 \\
(.048)^{* *}\end{array}$ & $\begin{array}{l}-0.595 \\
(.037)^{* *}\end{array}$ & $\begin{array}{l}-0.133 \\
(.05)^{* *}\end{array}$ & $\begin{array}{c}-0.609 \\
(.038)^{* *}\end{array}$ & $\begin{array}{l}-0.143 \\
(.052)^{* *}\end{array}$ & $\begin{array}{c}-0.463 \\
(.041)^{* *}\end{array}$ & $\begin{array}{c}-0.182 \\
(.055)^{* *}\end{array}$ \\
\hline (b) $\beta^{\text {ne }}$ & $\begin{array}{l}-1.000 \\
(.006)^{* *}\end{array}$ & $\begin{array}{l}-0.759 \\
(.008)^{* *}\end{array}$ & $\begin{array}{c}-0.935 \\
(.006)^{* *}\end{array}$ & $\begin{array}{l}-0.634 \\
(.008)^{* *}\end{array}$ & $\begin{array}{l}-1.097 \\
(.007)^{* *}\end{array}$ & $\begin{array}{l}-0.681 \\
(.01)^{* *}\end{array}$ & $\begin{array}{l}-0.826 \\
(.007)^{* *}\end{array}$ & $\begin{array}{l}-0.618 \\
(.01)^{* *}\end{array}$ \\
\hline $\begin{array}{l}\text { (c) } \theta \\
\text { (d) } \epsilon_{l, w}\end{array}$ & $\begin{array}{l}0.020 \\
1.985 \\
(.022)^{* *}\end{array}$ & $\begin{array}{l}0.018 \\
1.502 \\
(.03)^{* *}\end{array}$ & $\begin{array}{l}0.020 \\
1.856 \\
(.025)^{* *}\end{array}$ & $\begin{array}{l}0.018 \\
1.25 \\
(.032)^{* *}\end{array}$ & $\begin{array}{l}0.020 \\
2.175 \\
(.052)^{* *}\end{array}$ & $\begin{array}{l}0.018 \\
1.342 \\
(.071)^{* *}\end{array}$ & $\begin{array}{l}0.020 \\
1.638 \\
(.054)^{* *}\end{array}$ & $\begin{array}{l}0.018 \\
1.22 \\
(.074)^{* *}\end{array}$ \\
\hline Gender diff. $p$ value & 0.000 & & 0.000 & & 0.000 & & 0.000 & \\
\hline (e) $\epsilon$-implied pay gap & $\begin{array}{l}0.108 \\
(.01)^{* *}\end{array}$ & . & $\begin{array}{l}0.170 \\
(.014)^{* *}\end{array}$ & . & $\begin{array}{l}0.195 \\
(.058)^{* *}\end{array}$ & . & $\begin{array}{l}0.130 \\
(.069)^{* *}\end{array}$ & \\
\hline
\end{tabular}

Source: Brazilian RAIS, 1998-2001. Standard errors in parentheses. $N=8,145,107$

Asterisks denote levels of significance: ${ }^{*} p<0.05$ and ${ }^{* *} p<0.01$

Overall elasticity estimates are statistically significant and greater than zero for both males and females across each of the four models, presented in row (d) of Table 1. In each case, the male elasticity is larger and the difference is statistically significant. For the model controlling for firm factors (but not shared frailty, model (2)), male elasticity is 1.856 vs. female elasticity of $1.25(p<0.01)$. Across the models, male elasticity ranges from 1.638 to 2.175 while female elasticity ranges from 1.22 to 1.502 .

I display the monopsony-implied wage gaps in row (e). Ranging from 10.8 to $19.5 \mathrm{log}$ points (11.4 to 20.5\%), these gaps suggest higher male earnings due to a greater wagecoefficient quit response. This implied gap also compares to an actual raw wage gap of $16.4 \%$. For each model, the implied wage gap is statistically significant.

Models (3) and (4) account for shared frailties. Likelihood-ratio tests for zero shared frailty were run for each separation regression in these models and are rejected every time, suggesting statistically significant intra-group correlation: in terms of individual workers over time for model (3) and firms over many coworkers for model (4)..$^{5}$ Male elasticity is higher ( 2.175 vs. 1.638 ) and the implied pay gap is wider for the individual shared-frailty model compared to the firm-frailty model (19.5 vs. 13.0 log points). Of the four models, the firm-frailty model results in the lowest elasticity estimates for both male and female workers. In other words, stronger monopsony effects are estimated when accounting for firm characteristics and comparing coworkers of the same firm.

\subsubsection{Elasticity of quits vs. layoffs}

As noted above, a contribution of this study using the RAIS survey data is the ability to discern voluntary from involuntary quits. To see what effect the inclusion of layoffs would have on elasticity estimates, I compare voluntary separation regression results to involuntary separation results in Table 2. Elasticity estimates are computed using a simplified model for all quits vs. all layoffs.

$$
\epsilon_{l, w}=-2 \beta^{\text {Seps }} .
$$

In the estimation based on quits, both the elasticity measures and the implied gap compare very closely to results in the previous table, which are also estimated on quits alone. Results from this more parsimonious specification are essentially identical to the model (2) of Table 1, which uses similar controls. 
Table 2 Wage elasticity of voluntary vs. involuntary separations

\begin{tabular}{|c|c|c|c|c|}
\hline & \multirow{2}{*}{\multicolumn{2}{|c|}{$\begin{array}{l}\text { (1) } \\
\text { Quits }\end{array}$}} & \multirow{2}{*}{\multicolumn{2}{|c|}{$\begin{array}{l}\text { (2) } \\
\text { Layoffs }\end{array}$}} \\
\hline & & & & \\
\hline & Male & Female & Male & Female \\
\hline (a) $\beta^{\text {Seps }}$ & $\begin{array}{l}-0.926 \\
(.006)^{* *}\end{array}$ & $\begin{array}{l}-0.622 \\
(.008)^{* * *}\end{array}$ & $\begin{array}{l}0.148 \\
(.002)^{* *}\end{array}$ & $\begin{array}{l}0.251 \\
(.003)^{* *}\end{array}$ \\
\hline (b) $\epsilon_{l, W}$ & $\begin{array}{l}1.853 \\
(.012)^{* *}\end{array}$ & $\begin{array}{l}1.243 \\
(.016)^{* *}\end{array}$ & $\begin{array}{l}-0.297 \\
(.004)^{* *}\end{array}$ & $\begin{array}{l}-0.503 \\
(.007)^{* *}\end{array}$ \\
\hline (c) $\epsilon$-implied pay gap & $\begin{array}{l}0.172 \\
(.014)^{* *}\end{array}$ & & $\begin{array}{l}-0.583 \\
(.019)^{* *}\end{array}$ & \\
\hline
\end{tabular}

Source: Brazilian RAIS, 1998-2001. Standard errors in parentheses. $N=8,145,107$

Asterisks denote levels of significance: ${ }^{*} p<0.05$ and ${ }^{* *} p<0.01$

The relation between wages and layoffs are very different. The model (2) of Table 2 shows results of the hazard model of involuntary separations. Wage effects are statistically significant and greater than zero, suggesting that wage increases may contribute to an increase in the probability of being laid off. ${ }^{6}$ Female workers have a stronger effect in this regard-female workers are potentially put in more jeopardy of being laid off after a raise than men are.

Comparing quit to layoff results highlights the need to identify the nature of separations. Such distinction helps interpret the meaning of regression coefficients, especially in labor markets where layoff rates are high relative to quit rates, as in Brazil. Table 8 in the Appendix shows that layoff rates are $14.2 \%$ for males and 9.9\% for females, compared to quit rates of $2.4 \%$ for each. As shown, layoff elasticities move in a different direction than quit elasticities. Failure to distinguish the two potentially biases elasticity estimates toward zero and may fail to capture gender differences in worker separation decisions.

\subsubsection{Robustness across job duration models}

Previous literature has employed different specifications to estimate the job duration hazard. In their study of the German labor force, Hirsch et al. (2010) begin with an exponential proportional hazard model to estimate Eq. (10) assuming constant baseline hazard. The authors then check for robustness using a piecewise-constant exponential model, similar to the specification used in the previous section. The authors find gender elasticity comparisons to hold in this specification. With US data, Webber (2015) estimates a Cox proportional hazard model which does not require a constant baseline hazard. He compares results from time-varying and time-invariant specifications, finding only minor differences in results.

For robustness checks, I estimate a Weibull regression and test if the shape parameter $p=1$, indicating constant hazard. I also compare results to a Cox hazard model and perfor $m$ a proportional-hazard specification test (Schoenfeld 1982; Grambsch and Therneau 1994), testing whether covariates of the model do not vary with time-something that has not been reported in the previous monopsony literature. Additionally, I compare log likelihood across models to identify the best fit and Akaike Information Criterion (AIC) to find the best model (Cleves et al. 2008), also unreported in similar studies.

Table 3 compares elasticity estimates of various distributions. For simplicity, the male and female workers are computed together with gender incorporated into the model. The coefficient for being female is presented to indicate how gender is related to the probability of voluntarily separating from a job spell. 
Table 3 Elasticity estimates, by various hazard specification

\begin{tabular}{lccc}
\hline & $\begin{array}{c}\text { Exponential } \\
(1)\end{array}$ & Weibull & Cox \\
& $(2)$ & $(3)$ \\
\hline (a) $\beta^{\text {Seps }}$ & -0.811 & -0.625 & -0.581 \\
& $(.005)^{* *}$ & $(.005)^{* *}$ & $(.005)^{* *}$ \\
(b) Female & 0.132 & 0.099 & 0.094 \\
(c) $\epsilon_{l, w}$ & $(.005)^{* *}$ & $(.005)^{* *}$ & $(.005)^{* *}$ \\
& 1.622 & 1.249 & 1.162 \\
& $(.010)^{* *}$ & $(.010)^{* *}$ & $(.010)^{* *}$ \\
\hline
\end{tabular}

Source: Brazilian RAIS, 1998-2001. Standard errors in parentheses. $N=8,145,107$

Asterisks denote levels of significance: ${ }^{*} p<0.05$ and ${ }^{* *} p<0.01$

Elasticities using Weibull and Cox models are lower than those using the exponential distribution, suggesting a potential range of estimated wage-setting power. However, each estimate suggests positive elasticity. For the Weibull model, the shape parameter is estimated as $p=.537$ ( $p$ value $<0.01$ ), which rejects that the separation hazard is constant and indicates that hazard is monotone decreasing (Cleves et al. 2008). As a final check, the proportional hazard assumption (regression covariates do not vary with time) was tested with Cox model estimations. The wage coefficient $\left(\chi^{2}=2201.91, p<0.00\right)$, the female coefficient $\left(\chi^{2}=6.94, p<0.00\right)$, and the global test for combined covariates $\left(\chi^{2}=14187.80, p<0.00\right)$ suggest that the proportionality assumption is violated in the Cox specification and that a parametric model (i.e., exponential or Weibull) is more appropriate, as used in the full model above. The sign and statistical significance of wage coefficients and gender differences are robust across various hazard models. Differences across models, however, suggest the need for more testing, reporting, and greater understanding of hazard model assumptions and job spell duration when employing these models toward monopsony estimation.

\subsection{Disaggregation by region and sector}

A first extension to the model deals with gender elasticity differences for individual regions and sectors. Brazil is geographically large and diverse. The experiences of workers and the nature of firms in the densely forested North are likely quite different from the densely populated Southeast. Worker and firm characteristics also vary across different sectors, such as public administration compared to industry. For instance, over $55 \%$ of all female workers had a high school degree or more, but this varied greatly by region (48 to $61 \%$ ) and sector (10 to 91\%), as shown in Table 9 in the Appendix. Female workers made up over half of total workers in some sectors (i.e., medical and education) but under $40 \%$ of total workers and in large sectors such as industry and retail trade.

Gender pay differences also vary across region and sector, illustrated in Figure 1 in the Appendix. While the raw earnings gap (approximated by the difference in mean logmonthly wages) was $16.1 \%$ for all workers in 2001, it ranged from 7.1 to $20.8 \%$ across regions and 10.3 to $43.2 \%$ across sectors.

What does this variation mean for the relationship between gender differences in labor supply elasticity, the earnings gaps that are calculated from elasticity, and actual earnings gaps? Little research has attempted to disaggregate estimates and analyze the relationship across various markets. While Webber (2015) estimated labor supply elasticities for individual firms, he did not examine the relationship to gender differences. Other studies 
examined elasticity and earnings gaps for specific markets but do not include comparisons to other markets (Falch 2010; Ransom and Sims 2010; Depew and Sorensen 2011). This section opens a discussion of such concerns.

For comparisons across different markets, I move to a more parsimonious specification of the monopsony model, requiring only estimates of the wage elasticity to any voluntary job separation, restated here: ${ }^{7}$

$$
\epsilon_{l, w}=-2 \beta^{\text {vs }} .
$$

I compute the separation elasticity $\beta^{\text {vs }}$ by estimating a logit regression on the probability of voluntary separation from a job spell. In the discrete-time model, the wage elasticity of separations is estimated by the probability that an employed worker in the current job spell, time $t$, will voluntarily separate $s_{\mathrm{vs}}$ in $t+1$, to either employment or non-employment, as the logistic function:

$$
\operatorname{Pr}\left(s_{\mathrm{vs}}=1 \mid w_{i, t}, x_{i}, z_{j(i)}, v_{i, j(i)}\right)=\frac{\exp \left[\beta^{\mathrm{vs}} w_{i, t}+\alpha^{\mathrm{vs}} x_{i, t}+\gamma^{\mathrm{vs}} z_{j(i)}+v_{i, j(i)}\right]}{1+\exp \left[\beta^{\mathrm{vs}} w_{i, t}+\alpha^{\mathrm{vs}} x_{i, t}+\gamma^{\mathrm{vs}} z_{j(i)}+v_{i, j(i)}\right]}
$$

where vector $x_{i}$ represents observed worker characteristics, vector $z_{j(i)}$ represents observed firm characteristics, and $v_{i, j(i)}$ unobserved heterogeneity. I perform discretetime logit regressions as opposed to hazard modeling in the previous section for three reasons. First, I focus the analysis here to job separations in 2001, so as to minimize elasticity changes over time. Second, since numerous disaggregated regressions are estimated, the logit model allows for faster computation and easier implementation. Third, logit regression allows for more straightforward interpretation of Oaxaca-Blinder decomposition results in the next section. I check for robustness of overall results by estimating a conditional logit model with firm fixed effects. Additionally, elasticity estimates from logit regressions can easily be tested for statistical differences.

I again use a 10\% sample of the Brazilian Relação Anual de Informações Sociais (RAIS), which captures all formal worker job spells and uniquely identifies employers. Estimations here are limited to observations for the year 2001. Voluntary separations are defined as any quit from the last employment spell in 2001. I measure earnings as the log of deflated monthly wages described in footnote 2 . Worker and firm controls are included in each model estimation, as in the previous section.

I first estimate male and female elasticities for the entire sample, controlling for region and sector; next, I estimate elasticity for five regions and 12 sectors separately, shown in Table $4 .{ }^{8}$ For all Brazilian workers in 2001, elasticity differences imply a gender earnings gap that closely resembles the actual earnings gap. Table 4 shows that male elasticities are higher than female elasticities (1.62 vs. $0.92, p<0.01) .{ }^{9}$ The gender difference in elasticity implies an earnings gap of $29.1 \%$ compared to the actual gap of $35.7 \%$. The actual, adjusted gap is estimated by a wage regression controlling for the same covariates as in the separations equation. As stated above, the raw wage gap is $16.1 \%$.

The elasticity estimates here are smaller than those from the hazard-model estimations of the previous section. In general, such bias toward zero is expected with the use of a discrete-time approach. As discussed in Manning (2003), unobserved heterogeneity would likely grow with the length of time gaps between observations, biasing elasticity 
Table 4 Wage elasticity and implied and actual wage gaps, by region and sector

\begin{tabular}{|c|c|c|c|c|c|c|c|}
\hline \multirow[b]{2}{*}{ Parameter } & \multicolumn{2}{|c|}{ Observations } & \multicolumn{3}{|c|}{$\epsilon_{l, W}=-2 \beta^{\mathrm{vs}}$} & \multicolumn{2}{|l|}{ Gaps } \\
\hline & Male & Female & Male & Female & $p$ value & Implied & Actual \\
\hline All & $1,338,108$ & 831,257 & $\begin{array}{l}1.62 \\
(.028) * *\end{array}$ & $\begin{array}{l}0.92 \\
(.036)^{* *}\end{array}$ & 0.00 & $\begin{array}{l}0.291 \\
(.028)^{* *}\end{array}$ & $\begin{array}{l}0.357 \\
(.0009)^{* *}\end{array}$ \\
\hline Midwest & 111,426 & 62,718 & $\begin{array}{l}1.515 \\
(.084)^{* *}\end{array}$ & $\begin{array}{l}0.528 \\
(.098)^{* *}\end{array}$ & 0.00 & $\begin{array}{l}0.744 \\
(.216)^{* *}\end{array}$ & $\begin{array}{l}0.362 \\
(.003)^{* *}\end{array}$ \\
\hline North & 57,905 & 38,911 & $\begin{array}{l}1.012 \\
(.133)^{* *}\end{array}$ & $\begin{array}{l}0.638 \\
(.207)^{* *}\end{array}$ & 0.128 & $\begin{array}{l}0.292 \\
(.269)\end{array}$ & $\begin{array}{l}0.302 \\
(.004)^{* *}\end{array}$ \\
\hline Northeast & 215,370 & 144,418 & $\begin{array}{l}1.045 \\
(.1)^{* *}\end{array}$ & $\begin{array}{c}0.089 \\
(.127)\end{array}$ & 0.00 & $\begin{array}{l}5.237 \\
(8.135)\end{array}$ & $\begin{array}{l}0.315 \\
(.002)^{* *}\end{array}$ \\
\hline Southeast & 724,193 & 432,573 & $\begin{array}{l}1.656 \\
(.037)^{* *}\end{array}$ & $\begin{array}{l}0.983 \\
(.047)^{* *}\end{array}$ & 0.00 & $\begin{array}{l}0.258 \\
(.032)^{* *}\end{array}$ & $\begin{array}{l}0.354 \\
(.001)^{* *}\end{array}$ \\
\hline South & 229,214 & 152,637 & $\begin{array}{l}1.893 \\
(.071)^{* *}\end{array}$ & $\begin{array}{l}1.342 \\
(.09)^{* *}\end{array}$ & 0.00 & $\begin{array}{l}0.142 \\
(.036)^{* *}\end{array}$ & $\begin{array}{l}0.378 \\
(.002)^{* *}\end{array}$ \\
\hline All industry & 297,420 & 121,131 & $\begin{array}{l}2.129 \\
(.072)^{* *}\end{array}$ & $\begin{array}{l}2.086 \\
(.115)^{* *}\end{array}$ & 0.752 & $\begin{array}{l}0.007 \\
(.021)\end{array}$ & $\begin{array}{l}0.399 \\
(.002)^{* *}\end{array}$ \\
\hline Construction & 117,959 & 7,413 & $\begin{array}{l}1.452 \\
(.098)^{* *}\end{array}$ & $\begin{array}{c}0.279 \\
(.352)\end{array}$ & 0.001 & $\begin{array}{l}1.715 \\
(2.68)\end{array}$ & $\begin{array}{l}0.198 \\
(.006)^{* *}\end{array}$ \\
\hline Retail trade & 169,832 & 105,032 & $\begin{array}{l}.883 \\
(.076)^{* *}\end{array}$ & $\begin{array}{l}0.79 \\
(.096)^{* *}\end{array}$ & 0.446 & $\begin{array}{c}0.063 \\
(.087)\end{array}$ & $\begin{array}{l}0.197 \\
(.002)^{* *}\end{array}$ \\
\hline Wholesale trade & 44,316 & 15,901 & $\begin{array}{l}1.205 \\
(.153)^{* *}\end{array}$ & $\begin{array}{l}0.899 \\
(.222)^{* *}\end{array}$ & 0.256 & $\begin{array}{l}0.154 \\
(.164)\end{array}$ & $\begin{array}{l}0.225 \\
(.005)^{* *}\end{array}$ \\
\hline Finance & 25,970 & 20,297 & $\begin{array}{l}2.25 \\
(.258)^{* *}\end{array}$ & $\begin{array}{l}1.873 \\
(.275)^{* *}\end{array}$ & 0.319 & $\begin{array}{l}0.062 \\
(.066)\end{array}$ & $\begin{array}{l}0.191 \\
(.005)^{* *}\end{array}$ \\
\hline Real estate & 156,122 & 63,450 & $\begin{array}{l}1.737 \\
(.075)^{* *}\end{array}$ & $\begin{array}{l}0.707 \\
(.095)^{* *}\end{array}$ & 0.00 & $\begin{array}{l}0.533 \\
(.123)^{* *}\end{array}$ & $\begin{array}{l}0.283 \\
(.003)^{* *}\end{array}$ \\
\hline Transport & 104,971 & 19,507 & $\begin{array}{l}2.163 \\
(.131)^{* *}\end{array}$ & $\begin{array}{l}1.765 \\
(.265)^{* *}\end{array}$ & 0.179 & $\begin{array}{l}0.071 \\
(.062)\end{array}$ & $\begin{array}{l}0.233 \\
(.004)^{* *}\end{array}$ \\
\hline Hotel and service & 88,483 & 101,133 & $\begin{array}{l}1.029 \\
(.097)^{* *}\end{array}$ & $\begin{array}{l}0.675 \\
(.094)^{* *}\end{array}$ & 0.009 & $\begin{array}{l}0.259 \\
(.12)^{*}\end{array}$ & $\begin{array}{l}0.229 \\
(.002)^{* *}\end{array}$ \\
\hline Medical & 16,506 & 55,576 & $\begin{array}{l}.774 \\
(.244)^{* *}\end{array}$ & $\begin{array}{l}0.935 \\
(.161)^{* *}\end{array}$ & 0.582 & $\begin{array}{l}-0.097 \\
(.179)\end{array}$ & $\begin{array}{l}0.174 \\
(.004)^{* *}\end{array}$ \\
\hline Education & 21,341 & 39,447 & $\begin{array}{l}.941 \\
(.176)^{* *}\end{array}$ & $\begin{array}{l}0.844 \\
(.137)^{* *}\end{array}$ & 0.662 & $\begin{array}{c}0.059 \\
(.138)\end{array}$ & $\begin{array}{l}0.139 \\
(.005)^{* *}\end{array}$ \\
\hline Pub. admin. & 184,085 & 261,556 & $\begin{array}{l}.583 \\
(.098) * *\end{array}$ & $\begin{array}{l}0.248 \\
(.086)^{* *}\end{array}$ & 0.01 & $\begin{array}{l}0.856 \\
(.551)\end{array}$ & $\begin{array}{l}0.383 \\
(.002)^{* *}\end{array}$ \\
\hline Agriculture & 90,639 & 16,768 & $\begin{array}{l}1.88 \\
(.092)^{* *}\end{array}$ & $\begin{array}{l}1.094 \\
(.262)^{* *}\end{array}$ & 0.005 & $\begin{array}{l}0.249 \\
(.145)\end{array}$ & $\begin{array}{l}0.272 \\
(.004)^{* *}\end{array}$ \\
\hline
\end{tabular}

Source: Brazilian RAIS, 2001

Asterisks denote levels of significance: ${ }^{*} p<0.05$ and ${ }^{* *} p<0.01$

toward zero. ${ }^{10}$ One should keep in mind that two other analytical choices may be driving differences with the previous section: (1) no differentiation between quits to employment and quits to non-employment and (2) analyzing separations only for the year 2001. While the gender difference suggests higher male elasticity, as before, the elasticity-implied gap is much larger.

Analysis at regional and sectoral levels illustrates wide variation in elasticities and wage gaps. The implied gap greatly overestimates the actual gap in certain cases, namely the Midwest region (74.4 vs. $36.2 \%$ ), and underestimates gaps in other cases, such as the Southern region (14.2 vs. $37.8 \%$ ).

Table 4 reemphasizes the importance of statistical testing for both differences in elasticity estimates and the combination of elasticities in the implied gap Eq. (2). In the case of the Northern region, the implied gap is $29.2 \%$, close to the actual gap of $30.4 \%$. However, neither the gender elasticity difference nor the implied gap is statistically significant from zero, due to a high variance in the female estimates. For agriculture, gender elasticities are significantly different $(1.88$ vs. $1.094, p<0.01$ ) but the implied gap of $24.9 \%$ is not. Among the five regions, gender elasticities are significantly different in four regions 
and the implied gap is significantly different in three regions. Among the 12 sectors, gender elasticities are significantly different in 5 and the implied gap is significantly different in 2 sectors (real estate and hotel and service). It is noteworthy that the female elasticity is higher than the male elasticity in only one subgroup (medical sector), although this difference is not statistically significant.

\subsection{Decomposition of voluntary separations}

The methods used in previous sections have focused on estimating the effect of one factor (earnings) on job separations, controlling to the extent possible the effects of other covariates. The reasons for voluntarily separating from a job include more than earnings. Job quality, family concerns, alternative opportunities, and access to information also factor into such decisions. How does the overall separation decision differ between men and women, and what role does wage elasticity play in the context of these other factors? Decomposing gender differences in the separation decision can highlight the size of wage effects relative to those of other covariates.

I use the Blinder-Oaxaca methodology (Blinder 1973; Oaxaca 1973) to decompose gender differences in voluntary separation rates. The gender difference in separations, defined as $R=\bar{Y}^{m}-\bar{Y}^{f}$, is broken into three parts, referred to as the endowment $(E)$, coefficient $(C)$, and interaction $(I)$ effects:

$$
R=E+C+I
$$

Since the outcome in question is the binary worker decision to quit, modeled by the logit Eq. (14), a non-linear decomposition is used with a weighting method described by Yun (2004), Fairlie (2005), and Sinning et al. (2008). The three components are essentially functions of observed variables $X^{m}, X^{f}$, and coefficients $\beta^{m}$ and $\beta^{f}$, detailed in the three lines of Eq. (16):

$$
\begin{aligned}
\bar{Y}^{m}-\bar{Y}^{f} & =\sum_{i=1}^{K} W_{\Delta X}^{i}\left[\overline{F\left(X^{m} \beta^{m}\right)}-\overline{F\left(X^{f} \beta^{m}\right)}\right] \\
& +\sum_{i=1}^{K} W_{\Delta \beta}^{i}\left[\overline{F\left(X^{f} \beta^{m}\right)}-\overline{F\left(X^{f} \beta^{f}\right)}\right] \\
& \left.+\sum_{i=1}^{K} W_{\Delta \beta}^{i}\left[\overline{\left[\overline{F\left(X^{m} \beta^{m}\right)}\right.}-\overline{F\left(X^{m} \beta^{f}\right)}\right]+\left[\overline{F\left(X^{f} \beta^{m}\right)}-\overline{F\left(X^{f} \beta^{f}\right)}\right]\right]
\end{aligned}
$$

where $F($.$) is the cumulative logistic density function. Endowment effects on the right-$ hand side of the first line represent how the difference in mean quit rates is due to gender differences in sample averages of observed variables $X^{m}-X^{f}$, weighted for variable contribution to overall effects $W_{\Delta X}^{i}$. Coefficient effects in the second line represent how the difference in quits is due to gender differences in coefficients $\beta^{m}-\beta^{f}$. The third line represents an interaction effect between the two.

One of the benefits of this model is that decomposition results can be interpreted in a counterfactual manner. Results are generally presented for total $E$ and $C$ effects as well as the component $E$ and $C$ effects of individual covariates. Component $E$ can be interpreted 
as how expected mean female quit rates would change if female workers had male characteristic levels. The $C$ component can be interpreted as how expected mean quit rates would change if female workers had male coefficients.

We pay particular attention to wage in terms of endowment and coefficient effects. The endowment effect of wage suggests how female rates would change if females had male wage levels. The coefficient effect of wage suggest how female rates would change if they had male separation elasticity, $\beta^{\mathrm{vs}}$.

Table 5 presents the Blinder-Oaxaca decomposition of the voluntary separation (quit) rate between males and females. ${ }^{11}$ The difference in mean rates is very small but statistically significant due to the large number of observations; the negative difference of .0008 indicates that the female quit rate was essentially the same as the male rate. An endowment effect of $.003(p<0.01)$ suggests that female quit rates would barely increase if females had similar levels of observed male characteristics. The overall coefficient effect is -.001 , suggesting that women would have slightly lower quit rates if they had male coefficients to various characteristics. Overall effects are near zero, suggesting little male-female difference.

Hidden within these minuscule overall differences, the wage effect shows strong gender differences in wage responses. The wage coefficient effect shows how the difference in mean separation rates would change if female workers had male wage coefficients, calculated from the coefficients used to compute wage elasticity $\epsilon_{l, w}=-2 \beta^{\mathrm{vs}}$. This elasticity-difference coefficient effect on the quit rate gap is $-.075(p<0.01)$, very large in relation to overall effects.

The negative coefficient effect is due to lower wage coefficients for males $\left(\beta_{\mathrm{vs}}^{m}=-0.810\right.$ vs. $\left.\beta_{\mathrm{vs}}^{f}=-0.460\right)$, a difference which serves to lower the gap in quit rates. The wage coefficient effect being less than zero suggests the following: were females to have the stronger male wage coefficients, the mean female quit rate would decrease, causing the quit gap to increase. This finding is in line with economic interpretations of quit elasticity and labor supply. Males have a stronger stay response to a marginal wage increase than females $\left(\left|\beta^{m}\right|>\left|\beta^{f}\right|\right)$. Stated differently, male workers have a higher leave response to a marginal wage cut than female workers, represented by a negative elasticity further from zero. Female workers have lower odds than men of staying in a job as wages rise or leaving a job as wages fall. This important insight is hidden by similar overall male and female quit rates.

To see how the wage endowment and coefficient effects relate to other variables in the decomposition, Table 6 presents the full detailed results. The wage coefficient has the largest effect on differences in gender quit rates, but it is countered (almost to zero) by differences in returns of other factors. ${ }^{12}$ In general, if females had male returns to education, sector, occupation, and experience, mean females would be expected to have higher volunteer quit rates.

Table 5 Oaxaca decomposition of quit rates, summary of results

\begin{tabular}{|c|c|c|c|c|c|c|c|c|}
\hline \multicolumn{3}{|c|}{ Mean quit rates } & \multicolumn{3}{|c|}{ Overall effects } & \multicolumn{3}{|c|}{ Wage effects } \\
\hline Male & Female & Difference & E & C & 1 & E & $C$ & I \\
\hline $\begin{array}{l}.0236 \\
(.0001)^{* *}\end{array}$ & $\begin{array}{l}.0244 \\
(.0002)^{* *}\end{array}$ & $\begin{array}{l}-.0008 \\
(.0002)^{* *}\end{array}$ & $\begin{array}{l}.003 \\
(.0003)^{* *}\end{array}$ & $\begin{array}{l}-.001 \\
(.0003)^{* *}\end{array}$ & $\begin{array}{l}-.002 \\
(.0003)^{* *}\end{array}$ & $\begin{array}{l}-.001 \\
(.0001)^{* *}\end{array}$ & $\begin{array}{l}-.075 \\
(.02)^{* *}\end{array}$ & $\frac{-.001}{(.0000)^{* *}}$ \\
\hline
\end{tabular}

Source: Brazilian RAIS, 2001. $N=2,169,365$

Asterisks denote levels of significance: ${ }^{*} p<0.05$ and ${ }^{* *} p<0.01$ 
Table 6 Oaxaca decomposition of voluntary separation rates

\begin{tabular}{lll}
\hline & Endowments & Coefficients \\
\hline In(wage) & -.001 & -.075 \\
& $(.00006)^{* *}$ & $(.02)^{* *}$ \\
Age 30-39 & -.00003 & -.0009 \\
& $(7.50 \mathrm{e}-06)^{* *}$ & $(.001)$ \\
Age 40-49 & .0003 & .0004 \\
& $(.00006)^{* *}$ & $(.002)$ \\
Education: middle & -.00002 & .0007 \\
& $(.00003)$ & $(.0004)$ \\
Education: high school & .00004 & .003 \\
& $(.0001)$ & $(.001)^{*}$ \\
Education: college & -.001 & .004 \\
& $(.0002)^{* *}$ & $(.001)^{* *}$ \\
Sector dummies & .001 & .002 \\
& $(.0002)^{* *}$ & $(.0008)^{*}$ \\
Region dummies & .0002 & .0002 \\
& $(.00002)^{* *}$ & $(.0007)$ \\
Occupation dummies & .001 & .002 \\
& $(.0002)^{* *}$ & $(.0009)^{*}$ \\
Potential experience & -.0007 & .025 \\
& $(.0003)^{*}$ & $(.012)^{*}$ \\
Potential experience-squared & .0006 & -.006 \\
Firm variables & $(.0002)^{* *}$ & $(.004)$ \\
In(Employees) & .0003 & .001 \\
\% primary educated & $(.00004)^{* *}$ & $(.001)$ \\
\% high school educated & .003 & -.006 \\
\% white collar & $(.0002)^{* *}$ & $(.002)^{* *}$ \\
Constant & -.0009 & -.006 \\
& $(.00008)^{* *}$ & $(.002)^{* *}$ \\
Source Brat & .0002 & .001 \\
& $(.0001)$ & $(.001)$ \\
& .054 & $(.016)^{* *}$ \\
\hline
\end{tabular}

Source: Brazilian RA/S, 2001. $N=2,169,365$

Asterisks denote levels of significance: ${ }^{*} p<0.05$ and ${ }^{* *} p<0.01$

In terms of job mobility (i.e., the rates of quitting a job for other opportunities), a first glance suggests that the coefficient effects for wage counter the coefficient effects of other variables and that female workers have essentially the same probability of quitting as males. However, given the interpretation of the wage effect, female returns are lower than men in both areas: the negative wage coefficient $\left(\left|\beta^{m}\right|>\left|\beta^{f}\right|\right)$ suggests that women have a lower responsiveness to quit in the face of a wage decrease than men; the positive coefficient effects for other variables suggest that women have a lower responsiveness to gains in these characteristics than men. Only through decomposition procedures can we see that opposing effects which cancel overall gender quit rate differences are actually all pointing toward lower female job mobility.

\subsection{Comparison to other studies}

Statistical tests in the analyses above inform where gender differences and implied-wage gaps are greater than zero. I find this to be the case across various specifications of the model, reported above. However, statistical testing would temper the results of prior monopsony research. Table 7 summarizes elasticity estimates for three recent studies which did not include confidence bands or statistical tests for gender elasticity estimates, Barth and Dale-Olsen (2009), Hirsch et al. (2010), and Booth and Katic (2011). I calculate confidence intervals by a linear combination of standard errors and $\beta$ coefficients 
Table 7 Confidence intervals of male and female elasticities_implications for three studies

\begin{tabular}{|c|c|c|c|c|}
\hline \multicolumn{5}{|c|}{ Barth and Dale-Olsen (2009), Table 5} \\
\hline \multirow[b]{2}{*}{ Method 1: quits } & \multicolumn{2}{|c|}{ Low education } & \multicolumn{2}{|c|}{ High education } \\
\hline & Male & Female & Male & Female \\
\hline$\epsilon_{l, W}$ & 1.492 & 1.142 & 1.182 & $1.088^{\mathrm{a}}$ \\
\hline SE & 0.08 & 0.058 & 0.126 & 0.084 \\
\hline \multirow[t]{2}{*}{$\mathrm{Cl}$} & {$[1.34-1.65]$} & {$[1.03-1.26]$} & {$[0.94-1.43]$} & {$[0.92-1.25]$} \\
\hline & \multicolumn{2}{|c|}{ Low education } & \multicolumn{2}{|c|}{ High education } \\
\hline Method 2: excess turnover & Male & Female & Male & Female \\
\hline$\epsilon_{l, W}$ & 1.710 & 1.170 & 1.098 & $0.840^{\mathrm{a}}$ \\
\hline SE & 0.088 & 0.054 & 0.12 & 0.082 \\
\hline $\mathrm{Cl}$ & {$[1.54-1.88]$} & {$[1.06-1.28]$} & {$[0.86-1.33]$} & {$[0.68-1]$} \\
\hline \multicolumn{5}{|l|}{ Hirsch et al. (2010), Table 1} \\
\hline & \multicolumn{2}{|l|}{ Model 1} & \multicolumn{2}{|l|}{ Model 2} \\
\hline & Male & Female & Male & Female \\
\hline$\epsilon_{l, W}$ & 3.241 & $1.864^{\mathrm{a}}$ & 2.681 & $1.917^{\mathrm{a}}$ \\
\hline SE & 0.456 & 0.242 & 0.265 & 0.176 \\
\hline \multirow[t]{3}{*}{$\mathrm{Cl}$} & {$[2.35-4.13]$} & {$[1.39-2.34]$} & {$[2.16-3.2]$} & {$[1.57-2.26]$} \\
\hline & \multicolumn{2}{|l|}{ Model 3} & \multicolumn{2}{|l|}{ Model 4} \\
\hline & Male & Female & Male & Female \\
\hline$\epsilon_{l, W}$ & 3.656 & 2.586 & 2.489 & 2.145 \\
\hline SE & 0.051 & 0.073 & 0.050 & 0.066 \\
\hline $\mathrm{Cl}$ & {$[3.56-3.76]$} & {$[2.44-2.73]$} & [2.39-2.59] & {$[2.02-2.27]$} \\
\hline \multicolumn{5}{|l|}{ Booth and Katic (2011), Table 3} \\
\hline \multirow[t]{2}{*}{ Method 2} & \multicolumn{2}{|l|}{ With controls } & \multicolumn{2}{|c|}{ Tenure controls } \\
\hline & Male & Female & Male & Female \\
\hline$\epsilon_{l, W}$ & 0.760 & $0.610^{\mathrm{a}}$ & 0.461 & $0.409^{\mathrm{a}}$ \\
\hline SE & 0.156 & 0.199 & 0.165 & 0.208 \\
\hline $\mathrm{Cl}$ & {$[0.45-1.07]$} & {$[0.22-1]$} & {$[0.14-0.78]$} & {$[0-0.82]$} \\
\hline
\end{tabular}

reported in the papers and indicate with an "a" where gender elasticity differences cannot be said to be statistically significant and different from zero due to overlapping confidence bands. ${ }^{13}$

This occurs in five of the ten comparisons shown. Standard error and confidence interval calculations using delta method ${ }^{14}$, or similar bootstrapping methods, account for covariance of multiple $\beta$ coefficients and would be superior to the back-of-the-envelope calculations provided in Table 7. These calculations may be conservative since they do not account for covariance.

For Barth and Dale-Olsen (2009), gender elasticity differences for "high education" are not statistically significant. For Hirsch et al. (2010), models without firm effects show no difference, and for Booth and Katic (2011), both models with controls show no difference. While each of these studies argue that gender pay differences partially arise due to monopsonistic discrimination and search frictions, the lack of statistical significance suggests the need for further analysis and robustness checking. For instance, gender differences in elasticity with overlapping confidence bands cannot be said to imply any of 
the gender gap. Thus, differences between significant and non-significant results, as well as other possible reasons for the earnings gap, must be highlighted.

\section{Conclusions}

This paper focuses on the job transitions of formal-sector workers in Brazil and examines whether a dynamic model of monopsony helps explain gender wage differences. I estimate gender differences in the wage elasticity of voluntary job separations for the years 1998-2001. Overall elasticity estimates are positive for both males and females; differences are statistically significant with higher elasticity for males. With the full sample, I estimate four specifications, two of which control for shared-frailties (worker and firm) and find significant gender differences in each. Across the models, male elasticity ranges from 1.638 to 2.175 while female elasticity ranges from 1.22 to 1.502 . The wage gaps predicted by elasticity differences range from 11.4 to $20.5 \%$, compared to an actual wage difference of $16.4 \%$. These results add to a growing body of evidence that employers have an ability to engage in wage discrimination, paying lower relative wages to groups with lower wage elasticity-female workers in this case.

The methods and results of this paper contribute to the monopsony literature in a number of ways. First, knowing the reason for job separations is critical, as elasticity estimates based on hazard models of quits vs. layoffs produce very different wage coefficients. The predicted relationship between labor supply elasticity and wage is premised on the voluntary movement of workers. The RAIS differentiates quits from layoffs, something not possible in much of the labor data that monopsony models have been previously estimated on. While estimates for quits alone produce results predicted by the model (i.e., an upward-sloping labor supply curve and higher male elasticity and wage), estimates based on layoffs produce opposite effects. The failure to distinguish the two potentially biases elasticity estimates toward zero. This may fail to capture gender differences in worker separation decisions, especially if layoffs occur at high rates relative to quits.

Second, I find that the sign of wage coefficients in the hazard model of voluntary separations is robust to various distributions. As the use of hazard functions depends on several strong assumptions (i.e., constant baseline hazard, proportionality), the reporting of tests is critical to understanding the reliability of empirical monopsony studies. For instance, I find that the exponential distribution produces higher elasticity estimates than Weibull. However, both may be more appropriate than a Cox model, due to the latter failing proportionality hazard assumption tests. Additionally, tests of the shape of the hazard show that it is not constant, as assumed in the exponential model. The use of a more flexible piecewise constant model (as used in the main specification) seems appropriate.

Third, I find that several simplifications produce results similar to the main findings, namely using different estimation methods (logit regressions), a more parsimonious elasticity model (combining the separations to employment and non-employment), and a focus on separations for the year 2001. Exploring gender elasticity differences for specific subsamples of the data, I find similar results across regions. Sector disaggregation produces much more variability, with significant differences in gender elasticity found for 5 of 12 sectors.

Fourth, I supplement the main findings by using Blinder-Oaxaca methods to decompose the separation rate and analyze the effects of wage elasticity in relation to other factors that affect voluntary separation decisions. Although the gender gap in voluntary 
separation rates is very small, the analysis presented herein illustrates how the model can be used to determine the extent to which wage elasticity may explain such a gap. The negative wage coefficient effect $\left(\left|\beta^{m}\right|>\left|\beta^{f}\right|\right)$ suggests that women are less likely to quit in the face of a wage decrease than men. However, positive coefficient effects for other variables, including education, sector, occupation, and experience, suggest a lower female quit response due to an increase in these characteristics compared to men. While quit rates are similar for both males and females (approximately $2 \%$ ), decomposition procedures show that opposing effects which cancel overall gender quit rate differences are actually all pointing toward lower female job mobility. The use of decomposition methods contributes to better understanding worker decisions through the monopsony model.

Finally, the computation of standard errors for labor supply elasticity highlights the areas where male and female elasticity are significantly different, strengthening the case that monopsony differences relate to earnings differences for these workers. Back-of-theenvelope calculations of confidence intervals for three previous studies on the gender pay gap find multiple instances where gender differences lack statistical significance and thus do not suggest any relation to earnings gaps. The technical implementation of these methods, interpretation of results, and identification of significant gender differences are important, as findings of gender pay gaps have implications for gender wage policies.

A number of limitations of the analysis presented in this paper should be noted. First, although results from disaggregation and decomposition methods were similar to the full hazard specification, firm fixed effects were not accounted for in these extensions. Controlling for intra-firm effects should be explored with the use of these methods in further research. Second, the RAIS does not measure labor supply variables that may affect the decision to work, such as the number of children and other workers in the household and other sources of income to the household. Great care should be taken in interpreting job separation results-are they capturing monopsony effects or are they capturing worker or firm effects that are not accounted for in the data?

Third, this analysis considers only employed, formal-sector workers. While the RAIS data is representative for all Brazilian workers employed in the formal sector, it does not account for non-employed, self-employed, and workers in the informal sector. Selection effects into the formal sector and the overall labor force are not accounted for here. This formal-sector-only analysis depends on the assumption that workers do not typically separate voluntarily from formal-sector jobs into informal-sector ones. Previous studies of the Brazilian informal sector find that numerous barriers prevent voluntary transitions from one sector to the another (Botelho and Ponczek 2011; Bosch and Maloney 2010; Bargain and Kwenda 2009). Workers instead utilize the informal sector for other reasons. Using 20 years of monthly, job transition data, Bosch et al. (2007) find that workers use informal work to avoid unemployment, perhaps after an involuntary separation from formal work. Additionally, workers in informal work tend to jump to higher-paying formal-sector jobs when they are available. The informal sector does not constrain labor market behavior in Brazil, but rather, it serves as a buffer to be used after being laid off or during economic downturns.

Given this evidence on formal-informal segmentation, informality unlikely affected our analysis of the separations data. Due to segmentation, few workers are likely to voluntarily move from formal to informal employment, leaving separations to employment estimates 
$\left(\beta^{e}\right)$ largely unaffected. Some of the separations to non-employment estimates $\left(\beta^{n e}\right)$ are potentially moves to an informal job. Botelho and Ponczek (2011) found that only $8 \%$ of formal-sector workers in 1 year had transitioned to the informal sector by the next year, for any reason (p. 448). Gender differences in informal vs. formal pay incentives were also unlikely to affect the results. Results of higher male wage elasticity of separating from formal-sector employment could be an artifact of greater male opportunities in the informal sector. However, Botelho and Ponczek (2011) also found that male workers actually experience a higher pay penalty from formal-to-informal job transitions than females do, suggesting that the informal sector did not contribute to higher male elasticity.

The strong evidence found for gender elasticity differences across workers suggests a need to identify the cause of such differences. Research should more closely analyze gender differences in preferences and constraints with regard to mobility-either in relation to the participation decision, to various occupations, or to formal-/informal-sector decisions. Preference differences may include risk preferences when considering entry into the informal sector (Chioda 2011) or those related to home and family decisions (World Bank 2012). Mobility preferences may be related to occupational choice, as female workers may choose jobs with greater flexibility as a trade-off for lower pay (i.e., to better help with childcare) (Goldin 2014). Regarding constraints, research should identify barriers that bind some workers to a given sector or occupation.

Few studies have attempted to measure monopsony power in lower- and middleincome countries, where it can be argued that monopsony conditions are more prevalent due to higher poverty rates, greater difficulty in starting businesses, poorer information technology and transportation infrastructure, fewer education opportunities, and lower unionization rates. One of the reasons for the lack of research in these countries is the lack of labor data that captures the earnings, tenure, and separations information required for dynamic monopsony estimation. Further research is needed in other developing countries. The methods used in this paper, which link wage elasticity of job transitions to earnings differences and statistically test for gender differences, can help researchers and policymakers better understand the persistence of the large gender pay gap that exists for much of the world.

\section{Endnotes}

${ }^{1}$ See (Menezes-Filho and Muendler, 2011, pp. 34-37) for further description of the RAIS.

${ }^{2}$ RAIS records earnings in multiples of the current minimum wage, which I transform into Brazilian Real deflated to the August 1994 price level, as in Hirakawa et al. (2010). Components of earnings include the following: wages; "salaries; extraordinary additions, supplements and bonuses; tips and gratuities; commissions and fees; contracted premia; overtime compensation for contracted extra hours; hazard compensation; executive compensation; cost reimbursement components if they exceed $50 \%$ of the base salary and are for travel or transfers necessary for the execution of the job; payments for periods of vacation, holidays and parental leave; vacation gratuities if they exceed 20 days of salary; piece wages; and in-kind remunerations such as room and board. As a rule, components are considered part of salary if they are taxable income or are subject to Brazilian social security contributions," (Filho et al, 2006, pp. 24-25). Data on other benefits to the job, such as health benefits or social security payments, are not captured by RAIS. 
${ }^{3}$ Other firm variables may be of interest. The RAIS does not have unionization information for the firm. While public-private ownership information is collected, the indicator variable for this was removed after initial estimates showed public ownership to be highly correlated with the sector variables and have no effect on hazard model estimates.

${ }^{4}$ Due to inability to use the "suest" package for combined frailty model estimates, I computed elasticity $\epsilon_{l, w}$ standard errors for these models through the combination of separation regression standard error estimates:

$$
\operatorname{SE}\left(\epsilon_{l, w}\right)=\sqrt{2\left[\theta^{2} \operatorname{Var}\left(\beta^{e}\right)+(1+\theta)^{2} \operatorname{Var}\left(\beta^{n e}\right)\right]} .
$$

I compute SEs for implied gaps by the combination:

$$
\mathrm{SE}(\mathrm{Gap})=\sqrt{\left(\frac{\mathrm{SE}\left(\epsilon_{m}\right)}{\epsilon_{m}}\right)^{2}+\left(\frac{\mathrm{SE}\left(\epsilon_{f}\right)}{\epsilon_{f}}\right)^{2}} .
$$

${ }^{5}$ Likelihood-ratio tests and full regression results are available upon request to the author.

${ }^{6}$ Causality from wage to layoff probability is not so straightforward. Jobs with a high layoff probability may pay higher wages to attract workers. The potential of wage and layoffs being simultaneously determined should be kept in mind when interpreting these results.

${ }^{7}$ See Depew and Sorensen (2011), Hirsch et al. (2010), and Manning (2003) for discussions on the assumptions required for this specification of elasticity.

${ }^{8}$ The economic interpretation of elasticity estimates rely on a number of assumptions that may limit this analysis. First, sectors and regions may not be considered "separate" to the extent that firms operate in different regions, or across sectors, and that workers are mobile across regions and sectors. This concern is highlighted by Webber (2015). Second, if the distribution of elasticities is conditional on regional and sectoral characteristics, then segmentation of the analysis by subsets of these variables may serve to truncate the dependent variable (Koenker and Hallock 2001). Third, as the dynamic monopsony model assumes a steady-state labor market, regional or sectoral growth relative to others may introduce bias that is less problematic when all regions and sectors are included in the full model. I hope to minimize these limitations by estimating the model over one time period, to limit regional and sectoral changes over time, and by disaggregating only by fairly broad geographical and sector boundaries. The potential benefits of this analysis, to analyze elasticity differences across many markets, should be considered along with these concerns.

${ }^{9}$ Similar differences are found using the firm fixed-effects model, where male elasticity is estimated at 1.34 compared to 0.90 female elasticity $(p<0.01)$.

${ }^{10}$ Manning (2003) shows this effect for a gamma-distributed $v_{i, j(i)}$ by taking logs of the survival function and the differential with respect to wage (pp. 103, 110-111).

${ }^{11}$ The model was estimated with Stata using the program of Jann (2008). Standard erro rs are computed using the delta method and take into account the variability induced by stochastic regressors. Checks were also performed with the program of Sinning et al. (2008), with little changes to the overall and wage endowment and coefficient results. 
${ }^{12}$ Oaxaca and Ransom $(1999,156)$ note that overall effects are invariant to the choice of reference group in categorical variables. These choices do have effects on the coefficient effects for these variables but not to the wage coefficient of interest here. As the focus is on the relationship of the wage coefficient to the overall coefficient effect, normalization concerns are not expected to affect this relationship.

${ }^{13}$ I calculate standard errors for overall elasticity based on the standard errors for $\beta$ estimates reported in the three studies. For Barth and Dale-Olsen (2009), $\operatorname{SE}\left(\epsilon_{l, w}\right)=2 * \mathrm{SE}\left(\beta^{\text {(seps) }}\right)$. For Hirsch et al. (2010), $\mathrm{SE}\left(\epsilon_{l, w}\right)=\sqrt{(-1-\theta)^{2} * \operatorname{SE}\left(\beta^{e}\right)^{2}+(-1+\theta)^{2} * \operatorname{SE}\left(\beta^{n e}\right)^{2}+(-1+\theta)^{2} * \operatorname{SE}\left(\beta^{r}\right)^{2}}$, assuming covariance between $\beta^{\text {ne }}$ and $\beta^{e}$ is zero. For Booth and Katic (2011), $\mathrm{SE}\left(\epsilon_{l, w}\right)=\sqrt{(-2 * \theta)^{2} * \mathrm{SE}\left(\beta^{e}\right)^{2}+(-2 * \theta)^{2} * \mathrm{SE}\left(\beta^{n e}\right)^{2}}$, assuming covariance between $\beta^{\text {ne }}$ and $\beta^{e}$ is zero. Back-of-the-envelope confidence bands are calculated as $\epsilon_{l, w} \pm 1.96 * \mathrm{SE}\left(\epsilon_{l, w}\right)$.

${ }^{14}$ See Kreuter and Valliant (2007) for a description of the delta method as implemented by Stata and used in the primary analysis of this study.

\section{Appendix}

Table 8 Descriptive statistics of male and female formal-sector workers

\begin{tabular}{|c|c|c|c|}
\hline & & Male & Female \\
\hline \multirow[t]{8}{*}{ Workers } & Age 20-29 & 0.266 & 0.247 \\
\hline & Age 30-39 & 0.450 & 0.444 \\
\hline & Age 40-49 & 0.284 & 0.309 \\
\hline & Ed: primary & 0.447 & 0.253 \\
\hline & Ed: middle & 0.268 & 0.222 \\
\hline & Ed: high school & 0.180 & 0.310 \\
\hline & Ed: college & 0.105 & 0.214 \\
\hline & Potential experience & 21.820 & 19.942 \\
\hline \multirow[t]{5}{*}{ Occupation } & Professional & 0.117 & 0.224 \\
\hline & Technical & 0.172 & 0.319 \\
\hline & White collar & 0.137 & 0.187 \\
\hline & Skilled labor & 0.395 & 0.129 \\
\hline & Unskilled labor & 0.128 & 0.121 \\
\hline \multirow[t]{13}{*}{ Sector } & All industry & 0.225 & 0.145 \\
\hline & Utilities & 0.017 & 0.006 \\
\hline & Construction & 0.092 & 0.010 \\
\hline & Retail trade & 0.121 & 0.119 \\
\hline & Wholesale trade & 0.033 & 0.019 \\
\hline & Finance & 0.020 & 0.028 \\
\hline & Real estate & 0.111 & 0.076 \\
\hline & Transportation & 0.081 & 0.023 \\
\hline & Hotel and service & 0.065 & 0.119 \\
\hline & Medical & 0.013 & 0.070 \\
\hline & Education & 0.017 & 0.051 \\
\hline & Public admin. & 0.139 & 0.316 \\
\hline & Agriculture & 0.067 & 0.020 \\
\hline \multirow[t]{5}{*}{ Region } & Midwest & 0.079 & 0.073 \\
\hline & North & 0.042 & 0.045 \\
\hline & Northeast & 0.158 & 0.172 \\
\hline & Southeast & 0.549 & 0.528 \\
\hline & South & 0.171 & 0.182 \\
\hline
\end{tabular}


Table 8 Descriptive statistics of male and female formal-sector workers (Continued)

\begin{tabular}{llll}
\hline Firms & Log workers & 4.802 & 5.509 \\
& Mean proportion of primary ed. workers & 0.601 & 0.441 \\
& Mean proportion of high school ed. workers & 0.282 & 0.356 \\
Job & Mean proportion of white collar workers & 0.466 & 0.686 \\
& Log monthly wage & 5.737 & 5.573 \\
& Tenure (years) & 4.582 & 5.665 \\
& Layoff rate & 0.142 & 0.099 \\
& Quit rate & 0.024 & 0.023 \\
Observations & Quits to employment & 0.0005 & 0.0004 \\
& Quits to non-employment & 0.023 & 0.023 \\
& Firms & 514,408 & 358,436 \\
& Workers & $1,916,791$ & $1,172,878$ \\
& Job spells & $5,064,045$ & $3,081,062$ \\
\hline
\end{tabular}

Source: Brazilian RAIS, 1998-2001

Table 9 Female characteristics and gender differences, by region and sector

\begin{tabular}{lllllll}
\hline & Age 20-29 & $\begin{array}{l}\text { High school/ } \\
\text { college }\end{array}$ & $\begin{array}{l}\text { Prof./mgr./ } \\
\text { tech. }\end{array}$ & $\begin{array}{l}\text { Potential } \\
\text { experience (years) } \\
\text { Female (Mean) }\end{array}$ & $\begin{array}{l}\text { Firm no. } \\
\text { workers }\end{array}$ & $\begin{array}{l}\text { Firm \% } \\
\text { white } \\
\text { collar }\end{array}$ \\
\hline All & 0.25 & 0.55 & 0.54 & 19.77 & 5.40 & 0.68 \\
Midwest & 0.25 & 0.50 & 0.58 & 19.81 & 5.60 & 0.72 \\
North & 0.23 & 0.61 & 0.64 & 19.81 & 5.86 & 0.75 \\
Northeast & 0.22 & 0.61 & 0.60 & 20.08 & 5.62 & 0.72 \\
Southeast & 0.26 & 0.55 & 0.52 & 19.56 & 5.39 & 0.68 \\
South & 0.25 & 0.48 & 0.50 & 20.05 & 5.00 & 0.63 \\
All industry & 0.30 & 0.30 & 0.20 & 20.54 & 4.47 & 0.27 \\
Construction & 0.29 & 0.54 & 0.46 & 19.36 & 4.53 & 0.39 \\
Retail trade & 0.40 & 0.50 & 0.57 & 17.55 & 2.49 & 0.72 \\
Wholesale trade & 0.35 & 0.56 & 0.54 & 17.70 & 3.19 & 0.68 \\
Finance & 0.23 & 0.92 & 0.73 & 16.59 & 4.17 & 0.99 \\
Real estate & 0.35 & 0.58 & 0.44 & 18.02 & 4.25 & 0.72 \\
Transport & 0.28 & 0.62 & 0.40 & 18.79 & 5.03 & 0.68 \\
Hotel and service & 0.26 & 0.33 & 0.28 & 21.38 & 3.93 & 0.66 \\
Medical & 0.25 & 0.60 & 0.58 & 19.11 & 4.53 & 0.86 \\
Education & 0.24 & 0.80 & 0.74 & 17.27 & 4.42 & 0.88 \\
Pub. admin. & 0.13 & 0.70 & 0.79 & 20.70 & 8.55 & 0.82 \\
Agriculture & 0.24 & 0.10 & 0.09 & 25.38 & 3.65 & 0.14 \\
\hline Soure Brat & & & & &
\end{tabular}

Source: Brazilian RAIS, 2001. N = 2,169, 365

aProf./mgr./tech. indicates the differences in rates of workers holding a professional, managerial, technical, or supervisory occupation

Employed, formal-sector workers, ages 20-49 years 


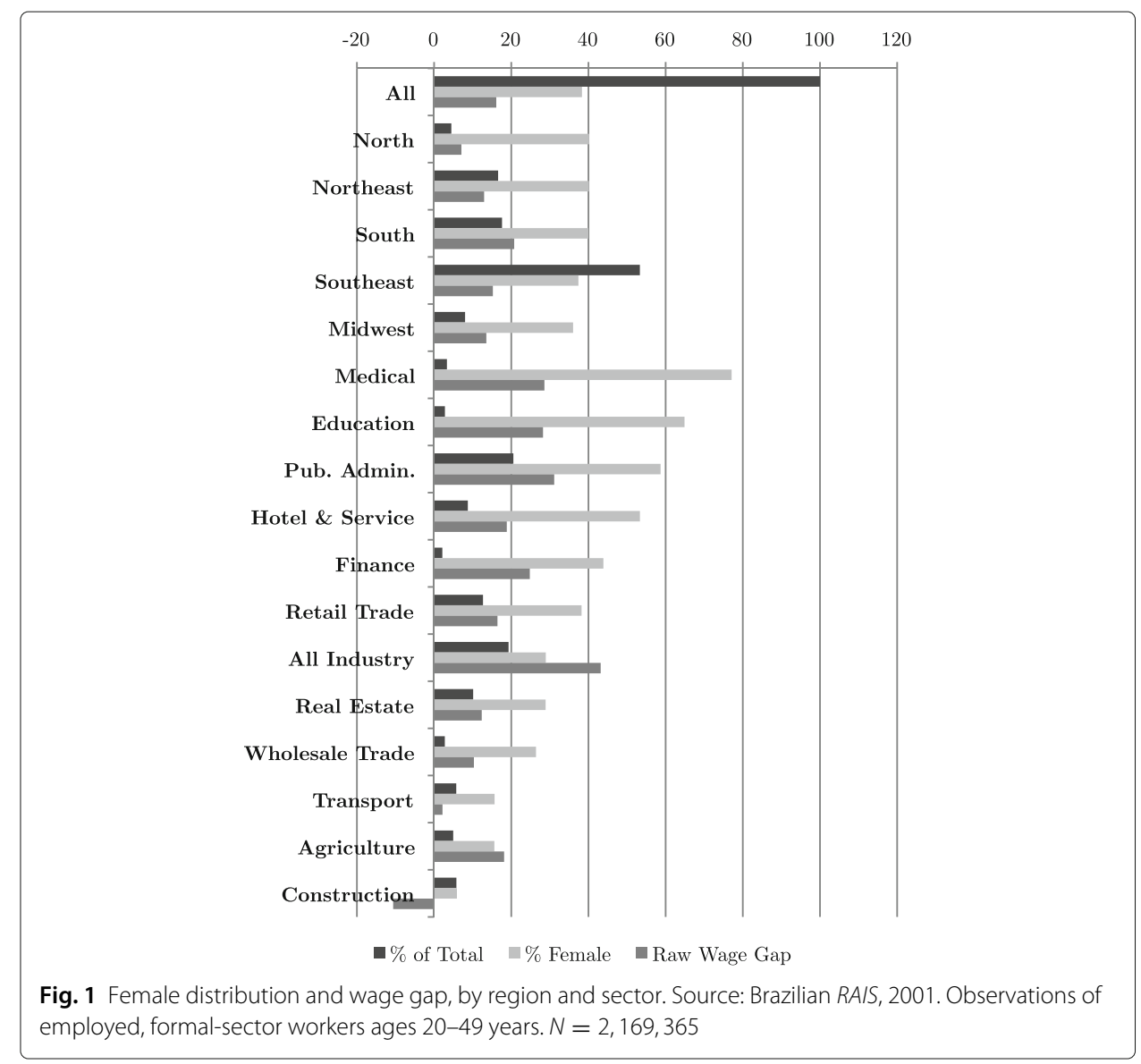

\section{Acknowledgements}

I would like to thank Sophie Mitra, Troy Tassier, H.D. Vinod, and Shirley Johnson-Lans for their feedback and Marc Muendler for sharing information on and giving access to the Brazilian RAIS.

Responsible editor: Hartmut F Lehmann

\section{Competing interests}

The IZA Journal of Development and Migration is committed to the IZA Guiding Principles of Research Integrity. The author declares that he has observed these principles.

\section{Publisher's Note}

Springer Nature remains neutral with regard to jurisdictional claims in published maps and institutional affiliations.

Received: 4 August 2016 Accepted: 16 March 2017

Published online: 10 August 2017

\section{References}

Arabsheibani GR, Carneiro FG, Henley A. Gender wage differentials in Brazil: trends over a turbulent era. Policy Research Working Paper 3148, World Bank. 2003. http://ssrn.com/abstract=1821918. Accessed Nov 2015.

Arbache JS, Loureiro PRA. The effect of a change in legislation on the wage gap in Brazil. Int J Econ Finance. 2012;4(2): 94-102.

Bargain O, Kwenda P. The informal sector wage gap: new evidence using quantile estimations on panel data. Working Papers 200916, Geary Institute, University College Dublin. 2009. http://ideas.repec.org/p/ucd/wpaper/200916.html. Accessed Nov 2015.

Barth E, Dale-Olsen H. Monopsonistic discrimination, worker turnover, and the gender wage gap. Labour Econ. 2009;16(5): 589-97. doi:10.1016/j.labeco.2009.02.004. http://www.sciencedirect.com/science/article/pii/S0927537109000281.

Behrman JR. Chapter 43: Labor markets in developing countries In: Ashenfelter OC, Card D, editors. Handbook of Labor Economics, Handbook of Labor Economics, vol 3, Part B. Elsevier; 1999. p. 2859-2939. doi:10.1016/S1573-4463(99)30029-8.

Blinder AS. Wage discrimination: reduced form and structural estimates. J Hum Resour. 1973;8(4):436-55. http://www. jstor.org/stable/144855.

Blundell R, Macurdy T. Chapter 27: Labor supply: a review of alternative approaches In: Orley CA, David C, editors. Handbook of Labor Economics, vol 3. Amsterdam: Elsevier Science B.V., Sara Burgerhartstraat; 1999. p. 1559-1695. 
Booth AL, Katic P. Estimating the wage elasticity of labour supply to a firm: what evidence is there for monopsony? Econ Rec. 2011:87(278):359-69.

Bosch M, Goni E, Maloney WF. The determinants of rising informality in Brazil: evidence from gross worker flows. Discussion Paper 2970, Institute for the Study of Labor. 2007. https://www.econstor.eu/bitstream/10419/34282/1/ 545572037.pdf. Accessed Nov 2015.

Bosch M, Maloney WF. Comparative analysis of labor market dynamics using markov processes: an application to informality. Labour Econ. 2010;17(4):621-631. doi:10.1016/j.labeco.2010.01.005. http://www.sciencedirect.com/ science/article/pii/S0927537110000096.

Botelho F, Ponczek V. Segmentation in the Brazilian labor market. Econ Dev Cult Chang. 2011;59(2):437-63. http://www. jstor.org/stable/10.1086/657127.

Brummund P. Variation in monopsonistic behavior across establishments: evidence from the Indonesian labor: Comparative Analysis of Enterprise Data Conference Paper; 2013. https://www.frbatlanta.org/-/media/documents/ news/conferences/2013/caed/E1Brummund.pdf.

Burdett K, Mortensen D. Wage differentials, employer size, and unemployment. Int Econ Rev. 1998;39(2):257-73.

Chioda L. Work and family: Latin America and the Caribbean women in search of a new balance. Technical report, Latin America and the Caribbean Gender Unit, World Bank, Washington, DC. 2011. http://siteresources.worldbank.org/ LACEXT/Resources/informe_genero_LACDEF.pdf. Accessed Nov 2015.

Cleves M, Gould WW, Gutierrez RG, Marchenko Y. An introduction to survival analysis using Stata, vol 2. Texas: Stata Press; 2008.

Danziger L. Endogenous monopsony and the perverse effect of the minimum wage in small firms. Tech. Rep. No. 2740, CES-IFO. 2009.

Depew B, Sorensen T. Elasticity of supply to the firm and the business cycle. Discussion Paper 5928, Institute for the Study of Labor. 2011. http://ftp.iza.org/dp5928.pdf.

Diamond P. Aggregate demand management in search equilibrium. J Polit Econ. 1982;90(5):881-94.

Fairlie RW. An extension of the Blinder-Oaxaca decomposition technique to logit and probit models. J Econ Soc Meas. 2005;30(4):305-16. http://iospress.metapress.com/content/E1GQMW31W5D4ENKA.

Falch T. The elasticity of labor supply at the establishment level. J Labor Econ. 2010;28(2):237-66.

Filho NAM, Muendler MA, Ramey G. The structure of worker compensation in Brazil, with a comparison to France and the United States. CESifo Working Paper Series 1643, CESifo Group Munich. 2006. http://ideas.repec.org/p/ces/ ceswps/_1643.html. Accessed Nov 2015.

Fox JT. Estimating the employer switching costs and wage responses of forward looking engineers. J Labor Econ. 2010;28(2):357-412.

Garcia LM, Nopo H, Salardi P. Gender and racial wage gaps in Brazil 1996-2006: evidence using a matching comparisons approach. Working Paper 567, IDB. 2009. http://ssrn.com/abstract=1821918. Accessed Nov 2015.

Goldin C. A grand gender convergence: its last chapter. Am Econ Rev. 2014;104(4):1091-119. doi:10.1257/aer.104.4.1091. http://www.ingentaconnect.com/content/aea/aer/2014/00000104/00000004/art00001.

Grambsch PM, Therneau TM. Proportional hazards tests and diagnostics based on weighted residuals. Biometrika. 1994;81 (3):515-26. doi:10.1093/biomet/81.3.515. http://biomet.oxfordjournals.org/content/81/3/515.abstract. http:// biomet.oxfordjournals.org/content/81/3/515.full.pdf+html.

Helpman E, Itskhoki O, Redding S. Inequality and unemployment in a global economy. Econometrica. 2010;78(4): 1239-83.

Hirakawa O, Muendler MA, Rauch JE. Employee spinoffs and other entrants: stylized facts from Brazil. Working Paper 15638, National Bureau of Economic Research. 2010. http://www.nber.org/papers/w15638. Accessed Nov 2015.

Hirsch B, Jahn EJ. Is there monopsonistic discrimination against immigrants? ILR Review. 2015;68(3):501-28.

Hirsch B, Schank T, Schnabel C. Differences in labor supply to monopsonistic firms and the gender pay gap: an empirical analysis using linked employer-employee data from Germany. J Labor Econ. 2010;28(2):291-330.

Jann B. The Blinder-Oaxaca decomposition for linear regression models. Stata J. 2008;8(4):453-79(27). http://www.statajournal.com/article.html?article=st0151.

Koenker R, Hallock K. Quantile regression: an introduction. J Econ Perspect. 2001;15(4):43-56.

Kreuter F, Valliant R. A survey on survey statistics: what is done and can be done in Stata. Stata J. 2007;7(1):1-211.

Lester R. A range theory of wage differentials. Ind Labor Relat Rev. 1952;5(4):483-500.

Loureiro PRA, Carneiro FG, Sachsida A. Race and gender discrimination in the labor market: an urban and rural sector analysis for Brazil. J Econ Stud. 2004;31(2):129-43.

Machado AF, Ribas RP, Penido M. Mobilidade entre estados de pobreza e inserção no mercado de trabalho: uma anãlise para o brasil metropolitano em 2004. Economia Aplicada. 2007;11:253-79.

Madalozzo R. Market and home production: gender differences in Brazil. Ibmec Working Papers WPE 160, Insper Instituto de Ensino e Pesquisa. 2009. http://ideas.repec.org/p/ibm/ibmecp/. Accessed Nov 2015.

Manning A. Monopsony in motion: imperfect competition in labor markets. Princeton: Princeton University Press; 2003.

Menezes-Filho NA, Muendler MA. Labor reallocation in response to trade reform. Working Paper 17372, National Bureau of Economic Research. 2011. http://www.nber.org/papers/w17372. Accessed Nov 2015.

Mortensen D, Pissarides C. Job creation and job destruction in the theory of unemployment. Rev Econ Stud. 1994;61 (3): 397-415.

Ñopo H, Daza N, Ramos J. Gender earnings gaps in the world. Discussion Paper 5736. IZA. 2011. http://gesd.free.fr/ iza5736.pdf. Accessed Nov 2015.

Oaxaca R. Male-female wage differentials in urban labor markets. Int Econ Rev. 1973;14(3):693-709. http://www.jstor.org/ stable/2525981.

Oaxaca RL, Ransom MR. Identification in detailed wage decompositions. Rev Econ Stat. 1999;81 (1):154-7. http://ideas. repec.org/a/tpr/restat/v81y1999i1 p154-157.html.

Pigou AC. The economics of welfare, 2nd edn. London: Macmillan and Co., Limited; 1924.

Ransom M, Oaxaca R. New market power models and sex differences in pay. J Labor Econ. 2010;28(2):267-89.

Ransom M, Sims D. Estimating the firm's labor supply curve in a "new monopsony" framework: schoolteachers in Missouri. J Labor Econ. 2010;28(2):331-55. 
Robinson J. The economics of imperfect competition. London: Macmillan and Co., Limited; 1933.

Schoenfeld D. Partial residuals for the proportional hazards regression model. Biometrika. 1982;69(1):239-41. doi:10.1093/biomet/69.1.239. http://biomet.oxfordjournals.org/content/69/1/239.abstract.

Sinning M, Hahn M, Bauer TK. The Blinder-Oaxaca decomposition for nonlinear regression models. Stata J. 2008;8(4): 480-92(13). http://www.stata-journal.com/article.html?article=st0152.

Skoufias E. Intertemporal substitution in labor supply: micro evidence from rural India. J Dev Econ. 1996;51(2):217-37. doi:10.1016/S0304-3878(96)00413-0.

Smith A. An inquiry into the nature and causes of the wealth of nations, 5th edn. London: Methuen \& Co., Ltd.; 1776 http://www.econlib.org/library/Smith/smWN.html.

Stigler G. Information in the labor market. J Polit Econ. 1962;70(5):94-105.

Stiglitz JE. Imperfect information in the product market. In: Schmalensee R, Willig R, editors. Handbook of Industrial Organization, vol 1. Amsterdam: Elsevier B.V., Radarweg 29; 1989.

Webber DA. Firm market power and the earnings distribution. Labour Econ. 2015;35:123-34.

World Bank. World development report 2012: gender equality and development. Washington, DC: World Bank; 2012. Yun MS. Decomposing differences in the first moment. Econ Lett. 2004;82(2):275-80. doi:10.1016/j.econlet.2003.09.008 http://www.sciencedirect.com/science/article/pii/S0165176503002866.

\section{Submit your manuscript to a SpringerOpen ${ }^{\odot}$ journal and benefit from:}

- Convenient online submission

- Rigorous peer review

- Immediate publication on acceptance

- Open access: articles freely available online

- High visibility within the field

Retaining the copyright to your article

Submit your next manuscript at $\gg$ springeropen.com 